\title{
POSTNATAL MORPHOLOGICAL AND HISTOCHEMICAL TYPE DIFFERENTIATION OF THE PORCINE MUSCLE FIBRES
}

\author{
J. KAMAN* \\ Department of Pathological Morphology, Faculty of Veterinary Medicine, University of Veterinary \\ and Pharmaceutical Sciences, 61242 Brno
}

Received January 20, 1993

\begin{abstract}
Kaman J.: Postnatal Morphological and Histochemical Type Differentiation of the Porcine Muscle Fibres. Acta vet. Brno 1995, 64:211-224.

Histological and histochemical detection of myosin ATPase, SDH and glycogen activity were used to study seven topographically and functionally different muscles of 23 Duroc pigs aged 2-4 hours, 7 days, and 1, 3 and 6 months. The aim of the study was to find out whether type differentiation of muscle fibres (MFs) is determined genetically or whether it is variable, and if so, in what ways, to what extent, and what is its relationship with "load myopathies", and to help answer the question of the "giant fibre", MF splitting, and of suitability of individual types of differentiation histochemical methods.

Our findings indicated that muscle fibres of neonates were fully morphologically and adequately histochemically differentiated, with MF II predominating. In addition to the basic MF I and II types, the myosin ATPase reaction helped us differentiate also the intermediary IIC type with its MS, SS and SM subtypes converging to type I; in some muscles we were able to demonstrate the IIA and IIB types differentiated to a different extent. In the first month of life, muscles were differentiated in: 1) muscles with a predominance of MF II, anaerobic (m. longissimus dorsi, $\mathrm{m}$. triceps brachii, $\mathrm{m}$. gracilis and $\mathrm{m}$. semimembranosus), metabolically equipped for "load myopathies"; 2) muscles with a high to dominant proportion (45-70\%) of oxidative MF I (m. tibialis cranialis, $\mathrm{m}$. trapezius, $\mathrm{m}$. sternomastoideus). No marked further conversion was found at the age of 3 months, and at the age of 6 months only a minimum conversion occurred. Deep zones of muscles belonging to group 1 muscles showed a higher relative ratio of MF I than the surface ones. Change in the proportion of MF I:MF II took place by gradual conversion of intermediary MFs IIC of their subtypes MS $\rightarrow$ SS $\rightarrow$ SM in type I.

Detection of SDH activity did not allow an objective type differentiation of MFs in piglets younger than 1 month. The glycogen content was not always in correlation with an adequate MF type. In glycolytic muscles, completely isolated MF IIB, of the "giant fibre" type, affected by dystrophic changes were identified. No longitudinally split MFs were demonstrated.
\end{abstract}

Pig, Duroc breed, muscle, fibre differentiation, type transformation, histochemistry

Breeds of pigs raised for meat that are intensively selected for extreme muscle growth in certain parts of the body, marked reduction of the proportion of fatty tissue and long trunks are, according to Haas (1972), characterised by insufficient adaptability, which is manifested by a number metabolic disorders. Bickhardt et al. (1972) characterised them as a specific syndrome and called them "load myopathies". Although different breeds exhibited considerable differences in their sensitivity to the syndrome (Hope 1984; U hrín et al. 1986), load myopathies have remained a topical issue because breeding animals with a genetic disposition to those disorders are still being used, causing considerable economic and breeding losses. Intensive research of load myopathies looking into many different aspects has been developed all around the world. It became obvious that functional and

\footnotetext{
*Address for correspondence:

J. Kaman

Sumavská 25

60200 Brno, Czech Republic
} 
morphological aspects of the muscle fibre present a host of questions related, in particular, to the type differentiation and MF distribution in the muscle bundle (MB), which determine the qualitative and quantitative character of the muscle.

Ashmore et al. (1972), Bader (1981) and Davies (1972) reported that it was genetically determined. Schlegel (1982) confirmed it both in the domestic and the wild pig. On the other hand, Binkhorst (1969), Beermann and Cassens (1977), Horák (1979), Suzuki and Cassens (1980), Salomon et al. (1983), Fazarinc et al.(1991) point out that the type distribution of MF in the muscle varies in relation to the age, breed, physical activity, diet, etc. Its relation to meat quality has been stressed by Ashmore et al. (1973), Kawaida et al. (1978) and Kulíšková and Uhrín (1986).

Research into porcine MFs has been carried out mainly on the $\mathrm{m}$. longissimus dorsi (Todorov and Petrov 1969; Swatland; Cassens 1973; Klosowska et al. 1976; Szentkuti et al. 1981; Salomon et al. 1983; Rotkiewicz 1981; Uhrín et al. 1986) or a few other, structurally analogous, muscles (Petrov 1970, Hende De Van et al. 1972; B ader 1983), which lead to a concept of their specifically identical structure and to a term "porcine muscle".

Differences are encountered in information on the incidence and importance of the socalled "giant fibres" in striated muscles (Todorov and Petrov 1969; Klosowska et al. 1976; Hraste et al. 1980; Szentkuti et al. 1981; Bader 1983; Finger et al. 1986; Fazarinc et al. 1991) and also on the longitudinal splitting of muscle fibres (Todorov and Petrov 1969; Petrov 1970; Schmalbruch 1976; Nøstvold 1981; Uhrín and Kulíšková 1985).

Our aim was to study the development of morphological and histochemical type differentiation of muscle fibres of Duroc pigs from their birth to the age of six months, and to find out if MF type distribution in muscles was stable, genetically determined, or if it was variable. If variable, we intended to identify the principle and process of type transformation and muscle fibres conversion and relate the results to the load myopathies syndrome, "giant fibres" and longitudinal muscle fibre splitting. We also wanted to assess histochemical methods used from the point of view of reliability, repeatability and, most importantly, objective results.

\section{Materials and Methods}

Twenty-three Duroc pigs of both sexes from a small breeding herd were used. They were divided into five age groups, i. e. 2 - 24 hours, 7 days, and 1, 3 and 6 months of age, with a mean body mass of 1.4, 2, 4.75, 28.5 and $105 \mathrm{~kg}$, respectively.

Muscle tissue was excised bioptically under general ether narcosis or Hypnodil i.p. with Stresnil i.m. premedication. In the case of the slaughter group, excisions were made immediately after slaughter from the $\mathrm{m}$. longissimus dorsi, $\mathrm{m}$. trapezius, caput longum $\mathrm{m}$. tricipitis brachii, $\mathrm{m}$. gracilis, $\mathrm{m}$. semimembranosus, $\mathrm{m}$. tibialis cranialis and $\mathrm{m}$. sternomastoideus. Excisions were divided in two parts. The smaller one, a cube $0.5 \mathrm{~cm}$ in size, was covered in talc and frozen to about $-190^{\circ} \mathrm{C}$. The blocks were then stored at $-60^{\circ} \mathrm{C}$. Later, at $-20^{\circ} \mathrm{C}$, they were cut into $10 \mu \mathrm{m}$ cryostat sections exactly perpendicular to muscle fibres and studied by histochemical (Dubowitz and Brooke 1973; Lojda and Papoušek 1978; Suzuki, Cassens 1980a) and, after hematoxylin-eosin staining (HE), histological methods.

Type classification of muscle fibres in series sections was based on the detection of myosin ATPase activity after alkaline ( $\mathrm{pH} 9.2 ; 9.4)$ and acid $(\mathrm{pH} 4.3 ; 4.6)$ preincubation, and a comparison of the two reactions. The other method used was based on the detection of the oxidative enzyme succinate dehydrogenase (SDH). The glycogen distribution in MF was ascertained by the periodic acid Shiff (PAS) reaction.

The rest of muscle excisions were fixed in a neutral $10 \%$ formaldehyde, HE stained and cut into $8-10 \mu \mathrm{m}$ paraffin histological sections. The thickness of MF in the sections and its variations were ascertained by means of an eyepiece and a stage micrometer.

Of the maze of classification systems, we chose the Brooke and Kaiser (1970) nomenclature for the MF type differentiation and the Suzuki and Cassens (1980 a,b) nomenclature for the differentiation of transformation subtypes of IIC intermediary muscle fibres. 


\section{Results}

Neonatal Period

M. longissimus dorsi - both cryostat and paraffin HE-stained histological sections showed full morphological differentiation with muscle fibres completely filled with myofibrils and peripherally located cell nuclei. Fibres were mostly tightly packed together and were becoming polygonal in cross-section (CS). The difference in the thickness between thicker primary fibres, now corresponding to type I fibres and thinner secondary fibres, now corresponding to MF II, was obliterated to various degrees. The muscle seemed to be relatively compact, and consequently the primary, and sometimes even secondary, muscle bundles (MBs) were not clearly delineated.

In spite of this predominant characteristic feature, the superficial zone of the muscle was less compact with clearly recognisable bundles, which did not lie close to each other, and neither did muscle fibres, which were circular in cross-section. Type I and II fibres can be easily differentiated without any special staining or histochemical reactions because the former may be up to 3 times thicker than the latter; MFs are fully lined with myofibrils. In thickness and topography, the intermediary MF IIC fall in between the MF I and MF II (Fig. $3 a, b)$. The remains of the myotubular lumen may sometimes be found in MF I which were situated in the centre of primary MBs. Fully differentiated neuromuscular spindles (NMS) were found regularly. They contained 1-3 markedly thick MFs and 3-8 (sometimes even more) 2-5 times thinner fibres. Cell nuclei were usually situated subsarcolemmally, but intrafibral location was also frequent.

Strikingly well-developed muscle fibres and bundles were found regularly around blood vessels. When taking specimens, we saw time and again that the $\mathrm{m}$. longissimus dorsi in Duroc pigs was much better supplied with blood than in any other breeds raised for meat.

Myosin ATPase detection - ATPase reaction following alkaline preincubation at $\mathrm{pH} 9.2$ (Fig. 3b) differentiated 1 , less frequently 2 , weakly reacting, frequently markedly thicker, alkali labile primary MF I in the centre of the primary muscle bundle. Dominant in the MB were 8-25 strongly reacting alkaline stable secondary MF II. Near the MF I, 1-3 (most frequently 2) muscle fibres could be distinguished which fell, by thickness and reaction intensity, between MF I and MF II. They were intermediary MF of type IIC, comprised of MS, SS and SM subtypes, differring from one another by the intensity of reaction when transformed to MF I. Their reliable differentiation and identification was only possible by a comparison between ATPase reactions after alkaline and acid preincubations.

Myosin ATPase reaction after acid preincubation at $\mathrm{pH} 4.3$ (Fig. 3a) presented an inverse image to the ATPase reaction after alkaline preincubation. The acid labile MF II, reacting strongly after alkaline preincubation, were now reacting weakly, while acid stable MF I, reacting weakly after alkaline preincubation, were now reacting strongly. Besides MF I, sections of different intensity were also recorded in a group of 2-3, rarely up to 5, MFs of the intermediary type IIC grouped around the MF I, which we considered conversion subtypes MS, SS and SM. The MS subtype reacted weakly after acid preincubation and strongly after alkaline preincubation, the SS subtype reacts strongly after both types of preincubation, and the SM subtype reacts strongly after acid preincubation and moderately after alkaline preincubation. Other MFs of the secondary developmental population of the primary MB belonged to MF II, which in neonates may already be differentiated in some places to a varying extent into MF IIA and IIB (Fig. 3a,b). While the MF IIA will maintain negative or almost imperceptibly positive ATPase reaction after acid preincubation, the MF IIB exhibited moderate to medium strong reaction. After alkaline preincubation, both types reacted strongly, although the IIA type almost imperceptibly less strongly than the IIB type.

SDH - the reaction was highly positive and constant. In transversal sections, groups of 
most frequently three MFs in the centre of primary bundles were found. They were conspicuous by a higher content of the reaction product, delineating the fibre contours not only intermyofibrilarly but frequently also subsarcolemmally. They were oxidative MF I and intermediary MF IIC, differing from the surrounding fibres of type II, which were only slightly delineated or completely undelineated and reacted with less intensity. For the age group studied, the SDH reaction cannot be used for an accurate MF type differentiation.

PAS reaction to glycogen is positive, to a considerable extent confluent and clearly differentiated in places. The non-reacting muscle fibres in the centre of the primary bundle correspond to the MF I type. The 1-3 adjoining fibres, with a very weak reaction, correspond to the intermediary MF IIC type. They differ from intensively reacting muscle fibres of the glycolytic type II on the MB periphery. PAS reaction was not, however, limited to muscle fibres only, and reactions in interfibral and interfascicular areas were fairly common.

M. triceps brachii, caput longum - mostly compact muscle, with a majority of primary muscle bundles fused together. Extrafusal fibres were completely filled with myofibrils whose cell nuclei were located peripherally, the thickness of both MF populations is approximately the same, with half of them still circular in cross-section. Neuromuscular spindles were also fully differentiated.

Routine myosin ATPase reaction identified an absolute predominance of type II fibres with 1 (sometimes 2) Type I fibres in the centre of the primary muscle bundle.

SDH reaction was clearly positive. The type differentiation of muscle fibres was still incomplete in places, elsewhere 1-3 more intensively reacting MFs can be found in the centre of primary MBs.

PAS reaction was highly positive (Fig. 2). The glycogen distribution was already more or less clearly differentiated in individual places. Muscle fibres of type I reacted negatively and 1-3 adjoining intermediary muscle fibres showed a weak reaction.

M. gracilis - morphologically fully differentiated (Fig. 4). Muscle fibres of both populations were still circular and relatively small in cross-section, and similar in thickness. Primary muscle bundles were clearly defined, muscle fibres in them were more or less separated with interstitium and circular, rather than polygonal, in cross-section.

ATPase reaction after alkaline preincubation showed that the muscle had an absolute predominance of MF II, with only one negatively reacting MF I in the centre of the primary MB. Two to four types of MF can usually be differentiated. Other types can be differentiated only at a comparison with acid ATPase. A reaction after preincubation at $\mathrm{pH} 4.3$ differentiated conversion subtypes MS, SS and SM, and even, although rarely, MF IIA and IIB (Fig. 4).

SDH reaction was positive. It, however, only allowed for differentiation between MF I and MF II. In some places, the PAS reaction identified glycogen only in fibres, elsewhere also between fibres, in some places uniformly in all fibres, in some places muscle fibres were differentiated into MF I and MF II, on a few occasions even IIC.

M. semimembranosus exhibited adequate features of full differentiation in two modifications. The deeper zone of the muscle seemed more compact, its closely adjoining muscle fibres of mostly polygonal CS mainly of the same thickness. In the remaining, superficial and less compact zone, muscle fibres and even muscle bundles communicated more loosely. Delineated to a varying extent by interstitium, they were of a corresponding circular CS and exhibited marked variability in thickness. Intrafibrilarly located cell nuclei and myotubule rudiments were very rare. Neuromuscular spindles were fully differentiated.

The detection of ATPase activity yielded predictable results. First of all, histochemical differentiation between alkali lability and acid stability of MFs on the one hand and alkali stability and acid lability on the other may not be very clearly developed yet. In parts of the 
section, or sometimes even on entire sections, reactions cannot be evaluated. Assessable areas and normally reacting histological sections exhibited a unified type structure of the primary bundle, which most frequently had a single centrally located MF I in it. Other histological sections showed two or three different zones in them. In the zones corresponding to the superficial and deep layers of the muscle, almost all primary bundles had 1 and 5-6 type I fibres respectively, with different levels of intensive reactions after acid preincubation and weak reactions after alkaline preincubation. Between the two, there was an intermediary level with 2-4 MF I. This documents histochemical as well as metabolic and functional differences in the structure of $\mathrm{m}$. semimembranosus, whose identification will depend on the type and site of sampling.

SDH reaction was, to a certain extent, analogous to the complexity of ATPase reactions. The results, generally speaking, were less conclusive than those in previous muscles. The PAS reaction, mostly limited to muscle fibres only, was monotonous and differentiated in places only.

M. tibialis cranialis - histological sections transversed the entire thickness of the muscle. They were characterised by an intensive HE affinity and basic attributes of fully differentiated MFs of mainly polygonal CS, which was due to a high compactness of the muscle. In spite of the predominantly uniform thickness of muscle fibres, thicker type I fibres may sometimes be identified and, exceptionally, also myotubes. Muscle fibres several times thinner than the rest were not exceptional. At a junction of several fibres, or where they were pushed against another fibre, they looked very much like a split or splitting fibres. Histochemically, they may resemble the nearest fibre but may be completely different.

Myosin ATPase reaction at $\mathrm{pH} 9.4$ preincubation will commonly differentiate three types of fibres, the dark-staining type II fibres, the light-staining or non-reacting type I fibres, and the intermediary type IIC fibres. The differentiated inversion at $\mathrm{pH} 4.3$ preincubation (Fig. 5) can differentiate between four types of muscle fibres, i. e. MF I, II and IIC, containing all three transformation subtypes MS, SS and SM. Most frequently, primary MBs contained 3 to 5, rarely 9 and - in aggregated bundles - up to 13 type I and IIC muscle fibres with a differentiated intensity of their reaction product. The higher number of acid stable fibres in the MB clearly differentiated the $\mathrm{m}$. tibialis cranialis from the previous muscles. What makes it particularly interesting is the fact that this muscle's primary MBs in neonates contained only one and exceptionally two type I muscle fibres. Markedly increased numbers of intermediary types of muscle fibres were found. Rather than concentrated in the centre of muscle bundles only, they were also disseminated in it in various patterns.

Type II muscle fibres, numerically predominating in neonates, may, in places, be histochemically differentiated into IIA and IIB types (Fig. 5).

Although it delineated fibres of primary bundles to various degrees, the SDH reaction made it only occasionally possible to identify the more intensively reacting fibres there. The PAS reaction was usually considerably different, and to a large extent confluent, in various parts of histological sections. In spite of that, more intensively reacting glycolytic fibres may - to a certain extent and in some places only - be differentiated from less intensively reacting oxidative fibres.

The $\mathrm{m}$. trapezius exhibited all the characteristics of an adequately morphologically differentiated muscle: muscle fibres were of the same thickness, they were filled with myofibrils, and the CS was polygonal. In spite of that, primary MFs sometimes contained 1-4 circular fibres of a slightly larger CS. Occasionally, this muscle also contained extremely thin fibres. HE staining was exceptionally intensive in histological sections in general and in oxidative and type IIC fibres in particular, which also partly differed in structure. It is, 
however, unsuitable for an objective identification of even the basic types of muscle fibres.

The myosin ATPase reaction after acid and $\mathrm{pH} 9.4$ preincubations can commonly differentiate 4 and 3 degrees of intensity, respectively. They corresponded to a differentiation of fibres into type I, II and IIC which, however, cannot be unambiguously identified without a comparison between acid and alkali ATPase. The main difference lies in the higher number of intermediary type IIC fibres or, more accurately, of their subtypes. Primary bundles most frequently contained 3-5, sometimes up to 8, intensively reacting type I and IIC muscle fibres, of which 1-3 were type I fibres, the remaining being type IIC subtypes, i. e. MS, SS and SM. These acid stable fibres were not as centrally located as they were in the first four muscles, and sometimes complicated MBs were found with 14 or more acid stable muscle fibres.

The SDH reaction was usually quite strong over the entire cross-section. Muscle fibres of higher and lower enzymatic activity corresponding to type I and IIC fibres and type II fibres respectively may be differentiated from each other. A reliable type differentiation in this age group and muscle, however, is not possible on the basis of the SDH reaction. The PAS reaction was frequently only local in character. Occasionally, weakly reacting lightcoloured type IIC, practically non-reacting type I, and more strongly reacting type II fibres may be differentiated. These reactions do not allow an objective type differentiation.

M. sternomastoideus - complete morphological differentiation was evident from a large number of HE mounts. In spite of that, thinner secondary fibres, or only very slightly thicker primary fibres - some with a hint of a tubular lumen - in the primary bundle, were still in evidence in places. In extrafusal fibres, cell nuclei were located clearly subsarcolemmally. In intrafusal fibres, on the other hand, they were located both intrafibrilarly and sarcolemmally. In this muscle, it is not at all difficult to find up to seven NMS in a histological section.

The detection of the myosin ATPase yielded a characteristic pattern. With alkaline preincubation, 2-3 and sometimes even 4 degrees of reaction can commonly be differentiated. In the primary bundle, 2-10 (most frequently 3-5) alkali labile fibres with a uniformly or non-uniformly weak reactions were located. After acid preincubation, the density of the reaction product allowed the differentiation of 4-5 types of fibres. Primary MBs contained 2-16 (the more complicated one up to 21) fibres of various acid stability. In many cases, they represented a half of the total number of fibres in the primary bundle, and sometimes even more. Such muscle fibres did not, however, form a central agglomerate but were as a rule irregularly distributed inside and also along the edges of primary bundles.

The SDH reaction - majority of muscle fibres was clearly delineated by subsarcolemmally located reaction product but a more intensive reaction, or a hint of it, corresponding to the localisation of type I or IIC fibres, occurred in places only. The PAS reaction was uniform in some places and differentiated in others. The most intensive reaction came from type II fibres, less intensive from type IIC, and the least intensive - or even negative - reaction from type I fibres. Glycogen was sometimes identified outside muscle fibres in primary and secondary bundles.

Examinations of muscles in the first age group pointed out to marked structural similarities between them. For further investigation in other age groups, we divided the muscles into two groups. Group 1 included the $\mathrm{m}$. longissimus dorsi, m. triceps brachii, $\mathrm{m}$. semimembranosus and $\mathrm{m}$. gracilis, and Group $2 \mathrm{~m}$. tibialis cranialis, $\mathrm{m}$. trapezius and $\mathrm{m}$. sternomastoideus.

\section{Piglets aged seven days}

Both groups of muscles were characterised by a more polygonal CS of their fibres. The muscles were also more compact, with a tendency to level off the differences in thickness 
between primary and secondary populations of fibres. Centrally located cell nuclei and remains of tubular lumina were a rare exception. In the glycolytic muscle type (m. longissimus dorsi), intensively HE-staining type I and IIC muscle fibres in the centre of primary muscle bundles was found frequently. This phenomenon, however, was not constant and did not suffice for type identification. In a 7-day-old piglet, we found a tendency towards "giant fibres" in an anaerobic type of muscles (m. triceps brachii).

ATPase reaction showed no fundamental differences from that in the neonates. It did, however, allow, generally speaking, a more unambiguous type identification. Reactions of myosin ATPase after alkaline, and particularly after acid, preincubations showed a more balanced thickness of both basic types of MFs. SDH - type differentiation of muscle fibres by means of SDH detection has clearly advanced and allows now a relatively clear identification of muscle fibres of type I as well as type II and IIC. In 7-day-old piglets, the $\mathrm{SDH}$ reaction allowed an assessment of the ratio between oxidative and anaerobic muscle fibres.

PAS reaction was constantly positive, medium to strong in intensity, bound to muscle fibres only. In relation to MF, it was either monotonous or differentiated. If monotonous, the intensity of its reaction was usually lower. The most intensive reaction was observed in type II, i.e. glycolytic, fibres, and the least intensive reaction, or none at all, in the type I, i.e. oxidative, fibres. The intensity of their reaction placed the intermediary IIC MFs in between the two.

\section{Piglets aged one month}

$\mathrm{HE}$ - the most important feature, besides a further increase in the compactness of muscle tissue due to the growing thickness of muscle fibres, is the thickness ratio inversion between types of muscle fibres. While in the early postnatal period generally, and in surface layers of anaerobic muscles particularly, muscle fibres of type I were thicker than those of type II, this disproportion disappeared within a week and at the age of one month, the type II fibres were thicker, particularly in the peripheries of primary MBs, i. e. in the region of type II fibres. In contrast with this development, extremely thin MFs were found in the region of thick MFs. These extra thin fibres, which may be several times thinner than the rest of fibres, usually adjoined the thick ones very closely and were strongly suggestive of "daughter" MFs.

In transversal sections, particularly the frozen ones, groups of usually 3-5 MFs with a "perforated" structure were clearly identifiable in primary bundles. The were more intensively HE-staining lipoid-rich type I and IIC, i.e. intermediary, fibres.

In animals of this age, myosin ATPase with alkaline and particularly with acid preincubation is able to differentiate not only between basic fibre types I and II, but also between all others, i.e. IIA, IIB and the conversion IIC type with its transformational subtypes MS, SS and SM.

As soon as in the 2nd week after birth, characteristic patterns of MFs in primary bundles may be discerned which were considered permanent and called ,a typical porcine muscle“ by many authors. They were represented by a cluster of type I and IIC fibres in the centre of the primary bundle and surrounded by type II (IIA, IIB) fibres, which made up an absolute majority of MFs in the primary bundle. We have, however, determined that this pattern exists only in muscles with a predominance of type II fibres, i. e. glycolytic ones, but not in muscles with a type I fibres predominance, and in completely oxidative muscles.

While in neonates, centres of such primary bundles typically contained a single type I fibre surrounded by 1-3, less frequently by up to 5 , type IIC fibres depending on the size of the bundle, and the rest of the bundle contained 8-25 type II fibres, in this age group (i. e. one 
month), we found 1-6 (most frequently 3) type I fibres, surrounded by 5-7 type IIC fibres (Fig. 8). The number of IIC MFs in the rest of the bundle was reduced by the fibres that have converted to type I. And while in neonates, converted fibres in muscles of this groups were mostly of the MS subtype, the now dominant is the SS subtype. The MF I precursors, the last of conversion subtype MS, and MS forms were also found there.

The fact that, at birth, Group 2 muscles (m. trapezius, $\mathrm{m}$. tibialis cranialis, $\mathrm{m}$. sternomastoideus) contained a higher number of intermediary fibres that Group 1 muscles can only be demonstrated by comparing results of the myosin ATPase after alkaline and acid preincubation. Although the differences may be considerable, they are not as big as the differences that take place during the postnatal MF conversion, leading to fundamental changes in the MF I : MF II ratio. In one-month-old pigs, type I fibres represented about 40$70 \%$ of all MFs in Group 2 muscles (Fig.10).

The most extensive conversion of type II into type I fibres was found in the $\mathrm{m}$. sternomastoideus, where type I MFs make up about $70 \%$ (Fig. 9a,b), i.e. it is a clearly tonic, red muscle although an absolute majority of its fibres at birth belonged to type II. Conversion was also responsible for the approximately $40 \%$ representation of type I fibres in the $\mathrm{m}$. tibialis cranialis although, at birth, the primary muscle bundle contained only 1-2 fibres of that type, and for their approx. 50\% representation in the m. trapezius.

Type II muscle fibres, i.e. also the IIA and IIB types in addition of the IIC type, are now also fully histochemically differentiated. Compared to the total number of type II fibres, the number of type IIA fibres is relatively low.

SDH reactions in individual muscles were quite different. The MF I and IIC reacted usually quite well. Type II muscle fibres were not clearly, if at all, delineated to be reliably differentiated from their neighbouring type II fibres, and their quantification on the basis of the SDH reaction was generally impossible. While the histochemical reaction product in Group 1 muscles was mostly or exclusively located interfibrilarly, in Group 2, and in the m. tibialis anterior particularly, it was also distributed subsarcolemmally to a large extent, which helped to clearly delineate both intermediary and, even more so, oxidative muscle fibres.

The PAS reaction - it was clearly defined but subdued in this age group. It allowed a reliable identification of non-reacting type I fibres in the middle of primary muscle bundles and strongly-reacting type II fibres as a whole. It was, however, difficult, if not downright impossible, to differentiate between the IIA, IIB and the intermediary IIC fibres.

\section{Pigs aged three months}

HE - overall histological characteristics were analogous with those in the previous age group. We occasionally found MFs of a perfectly round transversal CS, which contrasted with surrounding fibres (Figs 12b,15). They were also usually thicker, with enhanced or reduced susceptibility to HE-staining, and dystrophic changes of varying extent. They were most frequently identified on the periphery of muscle bundles. Appearing mostly in muscles with a predominance of Type II fibres, they resembled fibres described in literature as ,giant fibres".

In paraffin histological sections, we recorded several cases of a suspected longitudinal split of MFs. The findings were not, however, convincing enough, or the problem sufficiently investigated, for us to give an unambiguous answer to that question.

Myosin ATPase - using a comparison between acid and alkaline preincubation reactions, we were able to demonstrate continuing developments in the muscle fibre type differentiation. In the group of muscles comprising the $\mathrm{m}$. longissimus dorsi, $\mathrm{m}$. triceps brachii, $\mathrm{m}$. gracilis and $\mathrm{m}$. semimembranosus, type II fibres have retained their highly 
dominant position. Although transformations have about quadrupled the number of type I fibres, they still represent only about $12 \%$ of total MFs in those muscles. Among transformation types, the SS and SM subtypes are dominant, while the MS subtype is receding. While Group 2 muscles $(\mathrm{m}$. tibialis cranialis, $\mathrm{m}$. trapezius and $\mathrm{m}$. sternomastoideus) characterised by an exceptionally intensive and extensive conversion of type II into type I fibres which fundamentally changes the character of muscles have retained their pro-conversion character, it is much less intensive and has no major impact on the type structure of muscle fibres in the bundle.

In the m. semimembranosus of the neonates, we demonstrated differences in the type distribution of MFs in its superficial and deep layers. In the caput longum of the $\mathrm{m}$. tricipitis brachii of 3-months-old pigs, we made analogous findings. The minimum quantity of type I fibres in the superficial zone suggests a fast muscle, while the clearly larger number of fibres of this type in the deeper zone suggest a tendency to a tonic muscle. Figs 12a, b also demonstrate the presence of fibres from type IIA and IIB.

At this age, myosin ATPase can reliably differentiated muscle fibres of type II into MFs IIA (reacting negatively after acid preincubation) and MFs IIB (reacting weakly or moderately after the same preincubation). While the reaction after alkaline preincubation of both types of MFs is strong, that of type IIB fibres is somewhat stronger. The number of type IIA fibres is generally low compared to the number of type IIB fibres.

At this age, the SDH reaction completely delineated individual MFs of type II, but did not differentiate between types IIA and IIB. Oxidative fibres of type I and those of intermediary type IIC were characterised by a highly positive reaction. Type IIC fibres can be identified as a whole but individual transformation subtypes are unidentifiable. In order to accurately differentiate between type I and IIC, this method should be combined with inverse ATPase reaction after alkaline preincubation.

The PAS reaction was subdued to weak, and differed both in individual animals and muscles. Localised predominantly in type II fibres, glycogen was also occasionally demonstrated, although with difficulties, in type IIC fibres.

\section{Pigs aged six months}

HE - histological sections were characterised by marked polygonal character of the muscle fibres' CS and compactness of tissue. With the exception of the $\mathrm{m}$. tibialis cranialis and partly also the $\mathrm{m}$. sternomastoideus, MFs inside muscle bundles appeared thinner than along their peripheries. Thin ,daughter" fibres occurred only occasionally. Strikingly circular MFs, often thicker than the surrounding ones and suggestive of "giant fibres" were not difficult to find. These MFs, however, HE-stained more intensively than other MFs, with cell nuclei mostly subsarcolemmally. In these MFs, ATPase detection pointed to type II fibres.

ATPase - changes in the development of type differentiation were, compared to the situation at three months, conspicuous. Phasic muscles with an absolutely dominant proportion of type II fibres have retained the typical chessboard pattern of types I and II distribution. And although the number of type I fibres had increased 3-4 times, there were only few exceptions of more than 2-7 type I fibres in the primary bundle because their original number in neonates was so very small (1-2). Not all type I fibres were always in a cluster. Some may be quite isolated (Fig. 18). In muscles with predominantly type II fibres (e.g. m. longissimus dorsi), type I fibres made up about $12 \%$.

The thickness of MFs had changed considerably. Type II fibres were generally thicker than type I fibres. But there were MFs of type II which were clearly thinner than type I fibres. The thickest type II fibre in muscles with a predominance of muscles of this type was found 
in the $\mathrm{m}$. semimembranosus $(125 \mu \mathrm{m})$, while the thickest type I fibre in the same muscle was only $115 \mu \mathrm{m}$. Average thickness of its type II and I fibres was $96 \mu \mathrm{m}$ and $82 \mu \mathrm{m}$ respectively; in the $\mathrm{m}$. gracilis $85 \mu \mathrm{m}$ and $72 \mu \mathrm{m}$.

In spite of the fact that tonic muscles contained a higher percentage of intermediary muscle fibres as opposed to phasic muscles at birth, this difference was by far not as great as the one that occurred later due to postnatal increase of MF I type and decrease of MF II type. Although there was some conversion in these muscles observed between months 3 to 6 , the changes were not conspicuous. In $\mathrm{m}$. tibialis cranialis the conversion of muscle fibres from type II into type I reached approximately $45 \%$ (Fig. 14), in m. trapezius (Fig. 13ab) was this ratio ca $50: 50 \%$, and about $60-70 \%$ in $\mathrm{m}$. sternomastoideus.

It is interesting to note that the thickness of the two basic fibre types, i.e. type I and II, was very similar and also that they were relatively thinner than those in phasic muscles. In $\mathrm{m}$. trapezius, the maximum thickness was $91 \mu \mathrm{m}$, with an average of $81 \mu \mathrm{m}$ and $73 \mu \mathrm{m}$ (type I and II, respectively). Higher average values of type I fibres than type II fibres were also recorded in $\mathrm{m}$. tibialis cranialis. In the $\mathrm{m}$. triceps, type II fibres were thicker than type I fibres.

The SDH reaction was highly reliable in all cases. It provides a sharp differentiation between oxidative MFs on the one hand and anaerobic MFs on the other. Compared to the myosin ATPase method, it allowed for about a 30\% increase in the number of identified oxidative MFs. A more accurate identification of intermediary MF types and a differentiation of type I fibres was, however, rather questionable if it is not combined with another (conversion) method.

The PAS reaction in animals 6 months old was mild and selectively limited to type II fibres. In some cases, intermediary MFs also partly reacted.

\section{Discussion}

In newborn Duroc piglets, muscle fibres of skeletal muscles were fully morphologically and adequately histochemically differentiated. Among objective differentiation criteria, we included myofibrils embedded in MFs, subsarcolemmally located cell nuclei, a shift towards a polygonal CS, a tendency towards equalising thickness of the two populations of MFs (corresponding to Type I and II fibres) and histochemical (particularly myosin ATPase) differentiation if MFs.

The centre of primary bundles of the neonatal $\mathrm{m}$. longissimus dorsi, $\mathrm{m}$. triceps brachii, $\mathrm{m}$. gracilis and $\mathrm{m}$. semimembranosus contain 1 and exceptionally 2 type I muscle fibres. Attached to them are 1-3 (rarely 4) intermediary muscle fibres of type IIC. The m. trapezius contains 1-4 MFs of type I and up to 8 MFs of type IIC in their MS, SS and SM subtypes; the $\mathrm{m}$. sternomastoideus contains 2-4 MFs of type I and 2-10 usually differently reacting MFs of type IIC.

Davies (1972), Bader (1981) and Schlegel (1982) reported that type distribution of MFs in the $\mathrm{m}$. longissimus dorsi and $\mathrm{m}$. semimembranosus is genetically fixed and practically not subject to any changes. The list may be extended to include the $\mathrm{m}$. gracilis and caput longum $\mathrm{m}$. tricipitis brachii, i.e. muscles with an absolute predominance of type II fibres. In the other muscle group ( $\mathrm{m}$. tibialis cranialis, $\mathrm{m}$. trapezius and $\mathrm{m}$. sternomastoideus), however, we recorded an intensive conversion of type IIC fibres into type I fibres at the age of one month which led to a fundamental, even dominant, change in the muscle structure. The most extensive conversion (about 70\%) of MFs of type I in the muscle bundle was identified in the $\mathrm{m}$. sternomastoideus. At the age of three months, the progress of conversion was no longer very significant, and at 6 months it was completely insignificant. At the same time, the thickness of MFs peaked. The relative thickness of MFs 
changed compared the situation among neonates, but type II fibres were not always the thickest. These findings correlate significantly with results reported by Suzuki and Cassens (1980b) and, to a certain extent, with those reported by Fazarinc et al. (1991). Although significantly different with respect to early postnatal stages, our findings are also analogous with Horák's (1979) results from adolescent periods of his study involving miniature pigs. Although he used myosin ATPase detection after acid preincubation for histochemical differentiation, he failed to compare the results with an inverse reaction after alkaline preincubation and mistook intermediary type IIC and its MS, SS and SM subtypes (characterised by a strong, although differentiated, reaction after acid preincubation similarly to type I fibres) for type I fibres. This was mainly reflected in a significant overestimation of the number, and percentage representation, of type I fibres in the muscle bundle, in the characteristic of the dynamics of their development in the postnatal ontogeny and their interrelations with other muscle fibre types.

Objective description of the process of transformation of MF IIC subtypes can only be accomplished by comparing the myosin ATPase activity after alkaline preincubation with its inverse reaction after acid preincubation; the acid labile and alkali stable MS subtypes are transformed into acid and alkali stable SS subtypes, which, in their turn, through acid stable and alkali labile SM subtypes in muscle fibres of type I.

B eermann et al. (1978) recorded different histochemical patterns in superficial and deep zones of $\mathrm{m}$. semitendinosus. Using myosin ATPase reaction, we were able to differentiate three different zones in the neonatal $\mathrm{m}$. semimembranosus, with 1, 2-4 and 5-6 type I fibres in the superficial, medial or transitory and deep zones, respectively. A similar situation was found in the caput longum of the $\mathrm{m}$. triceps brachii in 3-month-old pigs. These findings point to histochemical type differences in the structure of individual muscles which may not be identified morphologically. If not taken into account when samples are taken from muscles and evaluated, it may lead to controversial results. In basic characteristics, the superficial and deep zones correspond to the phasic and tonic types of muscles, respectively.

We believe that methods used, rather than any real differences, are the true cause of discrepancies in type differentiation and muscle fibres distribution. Using black Sudan, Todorov and Petrov (1969), for instance, concluded that the differentiation between "dark" and "light" muscle fibres takes place in the first month. On the basis of myosin ATPase reaction after acid preincubation and NHD-TR reaction, Ho rák (1979) reported 5-10\% ratio of type I fibres already in neonatal muscles which show a predominance of type II fibres and in muscles of a mixed type in adults, and $20 \%$ ratio in muscles with type I dominance. Using SDH activity detection, Kulíšková and Uhrín (1986) found that the highest number of red MFs in glycolytic muscles is at birth and may reach up to $49.6 \%$. This is in contradiction not only with the results of MF type differentiation using myosin ATPase activity detection as reported by Suzuki and Cassens (1980b), but also with our results. Our findings showed that SDH reaction cannot reliably differentiate MF types in muscles of newborn piglets and, apparently, intermediary type IIC fibres were misinterpreted as type I fibres

Most authors report higher levels of glycogen in glycolytic type II fibres. Our results support this only partially. Similar conclusion was also made by Uhrín and Kulíšková (1985). Reactions were frequently confluent, on other occasions MFs had no glycogen. In animals of more advanced age where muscle excisions were not made intravitally, PAS reactions were mild. Glycogen seems to be quickly depleted post mortem, and glycolytic process may be more intensive in type II fibres. The stress before and during muscle excisions plays undoubtedly a certain role.

Giant fibres (GF) are described as a symptom of poorer quality of meat and load myopathies in slaughter pigs (Cassens et al. 1969; Klosowska and Klosowski 1976; 
Klosowska et al. 1976; Schmitt and Dumont 1980). The authors believe that the frequency with which they are found depends on the breed (higher incidence in stress-prone animals: Belgian Landrace and Pietrain), muscle type, diet and husbandry. Their conspicuously large size, circular transversal cross-section and possibly also morphological changes are linked to their enormous energy reserves of glycogen and function, intensive anaerobic glycolysis and impaired acid-base balance leading to hydropic degeneration (B a der 1982). Fazarinc et al. (1991) demonstrated that usually one muscle fibre of this kind at various stages of development can be found in a majority of primary muscle bundles in the $\mathrm{m}$. longissimus dorsi of a 6-month-old stressed pig.

Hraste et al. (1969), on the other hand, described GFs in pigs of primitive breeds, Finger et al. (1986) also in the wild pig, although Szentkuti et al. (1980) failed to confirm the finding in the wild pig.

We found an enormously thick muscle fibre of type II, i.e. a suspect giant fibre, at the periphery of the primary muscle bundle of a glycolytic muscle ( $\mathrm{m}$. triceps brachii) of a sevenday old Duroc piglet. Other characteristics of the GF (circular cross-section, intrafibral nucleus and possibly also some dystrophic changes) were only observed in older animals (Figs 12b, 15). They were histochemically identified as type IIB fibres (Fig. 12b). Structural dystrophic changes are already visible. They are the thickest fibres, insufficiently supplied with blood, glycolytic, with a demanding anaerobic metabolism, very vulnerable. On the other hand, they are characterised by the most intensive growth, guaranteeing an enormously fast increase in muscling, which is what these breeds of pigs are exclusively selected for.

In our study, fibres of the GF type were found only occasionally, and dystrophic changes only very rarely. Similar results were reported by T o d o r o v and P e t r o v (1969) in pigs 1-7 months old whose breed was, however, not mentioned. They considered them as light MFs transformed from dark MFs, as fibres that differentiated first and therefore to the highest degree that are, in a sense, worn-out, and the dystrophy as a physiological process. The minimum incidence of GFs in our material reflects positively on the husbandry used in the breeding herd which supplied us with animals, and a degree of resistance of the Duroc breed against "load myopathies“. The process in the fibres might be considered physiological to the extent of degenerative changes described by Martinov (1937) in human muscles which he called physiological degeneration and which was confirmed by other authors in various vertebrates.

We did not find any lengthways splitting MFs as they were very vividly described and documented by Todorov and Petrov (1969) in 2-3 year old pigs of contemporary breeds raised for meat. They arrived at a definitive conclusion that muscles grow postnatally not only by hypertrophy but also hyperplasia of muscle fibres. The general idea of splitting fibres is also supported by Nøst vold (1981). We are aware of the limited significance of our observations, but Uhrín and Kulíšková (1985) also failed to demonstrate any muscle fibre splitting in Duroc pigs. The incidence of fibres several times thinner than the rest of them in the primary muscle bundle in animals 1-6 months old might support the concept of new muscle fibres. New MFs are more likely to grow from satellite cells, rather than by their longitudinal splitting, as documented by Schmalbruch (1976) in his ultramicroscopy studies, and which, viewed by a light microscope, appear as fragments of longitudinal splitting of muscle cells.

Many authors consider a structural sample of a muscle bundle with 1-7 muscle fibres of type I in its centre and type II (IIA, IIB) fibres embedded in its periphery as a constant and typical model or unit of the „porcine muscle. It is a fiction, whose origin might be traced down to an almost exclusive study of the glycolytic $\mathrm{m}$. longissimus dorsi (or its structural analogue). This model does not apply to muscles with a higher proportion of oxidative muscle fibres, and even less so for typically oxidative, slow muscles. 


\section{Postnatální morfologická a histochemická typová diferenciace svalového vlákna prasete}

Prozkoumali jsme 7 topograficky a funkčně rozdílných svalů 23 prasat plemene Duroc ve věku 2-4 h, 7 d, 1, 3 a 6 měsíců histologicky a histochemicky detekcí aktivity myozínové ATPázy, SDH a glykogenu. Cílem bylo zjistit zda je typová distribuce svalových vláken (SV) ve svalech geneticky determinována anebo proměnná. Je-li proměnná, pak jakým způsobem, v jakém stupni, a jaký je její vztah $\mathrm{k}$ zátěžovým myopatiím. Cílem bylo také přispět k objasnění „giant fibres“ štěpení SV a vhodnosti typu diferenciační histochemické metody.

SV novorozencủ byla plně morfologicky a adekvátně histochemicky diferencována; dominovala SV II. Reakcí myozínové ATPázy jsme rozlišili kromě základních typů SV I a II též intermediární typ IIC a jeho podtypy MS,SS a SM konvergující v typ I; v některých svalech jsme prokázali i v různém stupni diferencované typy IIA IIB. Během 1. měsíce po narození se svaly rozlišily ve: 1 . svaly s prétrvávající prevevahou SVII, anaerobních (m. longissimus dorsi, $\mathrm{m}$. triceps brachii, $\mathrm{m}$. gracilis a $\mathrm{m}$. semimembranosus), metabolicky disponované pro zátěžové myopatie; 2 . svaly s vysokým až dominantním (45-70\%) podílem oxidativních SV $\mathrm{I}$ (m. tibialis cranialis, $\mathrm{m}$ trapezius, $\mathrm{m}$. sternomastoideus).Ve věku 3 měsícủ se již další konverze podstatně neprojevila, a zcela minimálně v 6 měsících. Hluboké partie svalů 1. svalové skupiny vykazovaly vyšší relativní podíl SV I než povrchové.

Detekce aktivity SDH neumožnila objektivní typovou identifikaci SV u selat mladších 1 měsíce. Obsah glykogenu nekoreloval vždy s adekvátním typem SV. V glykolytických svalech jsme identifikovali zcela ojedinělá, dystrofickými změnami postižená SV IIB, typu „giant fibres“. Neprokázali jsme podélně štěpená SV.

\section{References}

ASHMORE, C. R., ADDIS, P. B., DOERR, L. 1973: Development of muscle fibers in the fetal pig. J. Anim. Sci. 36:1088-1093

ASHMORE, C. R., TOMPKINS, G., DOERR, L. 1972: Postnatal development of muscle fiber types in domestic animals. J. Anim. Sci. 34:37-41

BADER, R. 1982: Histologische Befunde aus licht- und elektronmikroskopischen Untersuchungen an der Skelettmuskulatur von gesunden ausgemästeten Schweinen der Deutschen Landrasse. Zbl. Vet. Med. A, 29:458-476

BADER, R. 1983: Vergleichende Untersuchungen an der Skelettmuskulatur von Wild- und Hausschweinen. Berl. Münch. Tierärztl. Wschr. 96:89-97

BADER, R. 1981: Enzymhistochemische, histometrische, histologische und elektronmikroskopische Untersuchungen an der Skelettmuskulatur gesunder ausgemästeter Schweine der Deutschen Landrasse in unterschiedlichen Haltungssystemen. Berl. Freie Univ., Diss. Med. Vet.

BEERMANN, D. H., CASSENS, R. G. 1977: Indirect fluorescence of primary and secondary myofibers in developing porcine muscle. J. Histochem. Cytochem. 25: 439-442

BEERMANN, D. H. 1978: A second look at fiber type differentiation in porcine skeletal muscle. J. Anim. Sci. 46: 125-132

BICKHARDT, K., CHEVALIER, H. J.,GIESE, W., REINHARD, H. J. 1972: Akute Rückenmuskelnekrose und Belastungsmyopathie beim Schwein. Fortschritte der Vet. Med., Berlin/Hamburg, S.111

BINKHORST, R. A. 1969: The effects of training on some isometric contraction characteristics of a fast muscle. Pflügers Arch. ges. Physiol. Berlin, Göttingen, 309: 193-202

BROOKE, M. H., KAISER, K. K. 1970: Muscle fiber types: How many and what kind? Arch. Neurol. 23: 369-379

CASSENS, R. G., COOPER, C. C., BRISKEY, J. 1969: The occurrence and histochemical characterization of giant fibers in the muscle of growing and adult animals. Acta Neuropathol. 12: 300-308

DAVIES, A. S. 1972: Postnatal changes in the histochemical fibre types of porcine skeletal muscle. J. Anat. 113: 213-240

DUBOWITZ, V., BROOKE, M.H. 1972: Muscle biopsy: A modern approach. Saunders Company Ltd., London, $474 \mathrm{p}$.

FAZARINC, G., BAVDEK, S., LORGER, J. 1991: Postnatale histokemične in morfometrične sprembe $\mathrm{v}$ skeletnem mišičju domačega prašiča. Zb. Vet. fak. Ljubljana, 28: 151-165 
FINGER, W., DZAPO, V., WASMUTH, R. 1986: Morphometrische Untersuchung am m. longissimus dorsi von Schweinerassen unterschiedlicher Konstitution. Zschr. Zücht. Zuchtungsbiol. 103: 59-68

HAASE, S. 1972: Untersuchungen zur Erfassung des Adaptationsvermögens beim Hausschwein. Schriftreihe des Max-Planck-Inst. f. Tierzucht u. Tierernährung, Mariensee/Trenthorst, $98 \mathrm{p}$.

HANZLLKOVA, V. 1980 : Histochemical patterns in normal and splaylegged muscle fibers. Histochem. 67: 311319

HENDE VAN DEN, C., MUYLLE, E., OYAERT, W., ROOSE DE, P. 1972: Changes in muscle characteristics in growing pigs, histochemical and electron microscopic study. Zbl. Vet. Med. A, 19: 102-110

HORÁK, V. 1979: Heterogenita a ontogenetický vývoj typủ svalových vláken u miniprasat a drủbeže.(In Czech), $\mathrm{PhD}$. thesis, UUFG, Liběchov, $174 \mathrm{p}$.

HRASTE, A., ZOBUNDŽIJA, M., BEGO, U. 1980: Prilog pojevi divoskih vlakna u m. longissimus dorsi svinja primitivnich pasmina. Veter. Arch. 50: 51-59

KAMAN, J. 1995: Morphological and histochemical type differentiation of muscle fibers in newborn pigs: its relationship to topical myopathies. Acta vet. Brno 64:35-47

KAWAIDA, H., HIRATA, I., MIYAUCHI, Y., KANMATSUSE, N., KAKO, Y., KOJIMA, M. 1978: Studies on meat quality and its estimation technics of Kagoshima Berkshire. I. Correlation between muscle fibre diameter and some characteristics of longissimus dorsi muscle. Jap. J. Swine Husb. Res. 15: 22-28

KLOSOWSKA, D., KLOSOWSKI, B. 1976: Wstepne obserwacje nad wplywem sezonu na niektore cechy histologicznej budowy miesnia najdluszego grzbietu swiň rasy wielkej bialej polskiej. Zesz. probl. Post. Nauk. rol. 180: $447-451$

KLOSOWSKA, D., KLOSOWSKI, B., GRAJEWSKA, S. 1976: Histologiczny obraz mieśna najdluzszego grzbietu swiń mieszencov rasy Norweskiej landrace i Wielkej bialej polskej zywionych paszami o zroznicowanym poziomie bialka. Zesz. probl. Post. Nauk. rol. 180: 441-446

KULISKKOVÁ, L., UHRIN, V. 1986: Postnatálny rast jednotlivých typov svalových vláken niektorých svalov prasiat. Živoč. výr. 31: 143-152

LOJDA, Z., PAPOUŚEK, F. 1978: Základy histochemického prúkazu enzymú. Ústav dalš́ho vzdělávání zdravot. kádrù, Brno, 119 p.

NØSTVOLD, S. O. 1981: Anatomy of skeletal muscle tissue. Proc. Symp. „Porcine stress and solution to the meat quality“. Jeloy, Norway, 1980. Agricult. Food Res. Soc., Norway

PETROV, J. 1970: Porodni i polovi razlicija v diametyra na muskulnite vlakna i krechkostta na mesoto u prasta, otgleždani pri razlǐ̌en režim. Sp. Životnovydni nauki.7: 83-98

PETROV, J. 1976: Über die postnatale Entwicklung der Skeletmuskelzellen bei Schwein. Zbl. Vet. Med. C 5: 224243

ROTKIEWICZ, T. 1980: Badanie morfologiczne i histochemiczne miesnia nejdluszego grzbietu (musculus longissimus dorsi) u roznych ras swiń. Zesz. nauk. Wyz. Szk. roln. Olszt. 12: 49-93

SALOMON, F., MICHEL, G., GRUSCHWITZ, F. 1983: On the development of fiber types composition and diameter in porcine longissimus (Sus scrofa domesticus). Anat. Anz. 154: 69-79

SCHLEGEL, O. 1982: Untersuchungen über die Fasertypenverteilung und Fasertypenquerschnittsflächen in $\mathrm{m}$. longissimus dorsi und $\mathrm{m}$. semitendinosus von trainierten Haus- und immobil gehaltenen Wildschweinen. Inaug. Diss., Tierärztl. Hochschule, Hannover

SCHMALBRUCH, H. 1976: Muscle fiber splitting and regeneration in diseased human muscle. Neuropathol. and Applied Neurobiol. 2: 3-19

SUZUKI, A., CASSENS, R. G. 1980a: pH sensitivity of myosin adenosine triphosphatase and subtypes of myofibres in porcine muscle. Histochem. J. 12:687-693

SUZUKI, A., CASSENS, R. G. 1980b: A histochemical study of myofiber types in muscle of the growing pig. J. Anim. Sci. 51:1449-1461

SWATLAND, H. J., CASSENS, R. G. 1973: Prenatal development, histochemistry and innervation of porcine muscles. J. Anim. Sci. 36:343-354

SZENTKUTI, L. -NIEMEYER, B., SCHLEGEL, O.: 1981: Vergleichende Untersuchung von Muskelfasertypen mit der Myosin-ATPase-Reaktion im M. Longissimus dorsi von Haus- und Wildschweinen. Dtsch. Tierärztl. Wschr. 88:393-448

TODOROV, A., PETROV, J. 1969: Entwicklung und Veränderung der Skelettmuskelfaser (Differenzierung, Hyperplasie und physiologische Degeneration) beim Schwein nach der Geburt. Anat. Anz. 125: 88-108

UHRłN, V., KULfSKKOVÁ, L. 1985: Porovnanie typov svalových vláken roznych plemien a krížencov ošípaných. Proc. XIIth Genetic Days, Nitra, 234-236

UHRIN, V., KULIŠKOVÁ, L., POLTÁRSKY J., BULLA, J.1986: Mikroskopická stavba niektorých svalov ošípaných zaradených do hybridizačného programu. Živoč. výroba 31:839-847 
Plate I.

Kaman J.: Postnatalní sval. vlákna prasete... pp. 211-224.

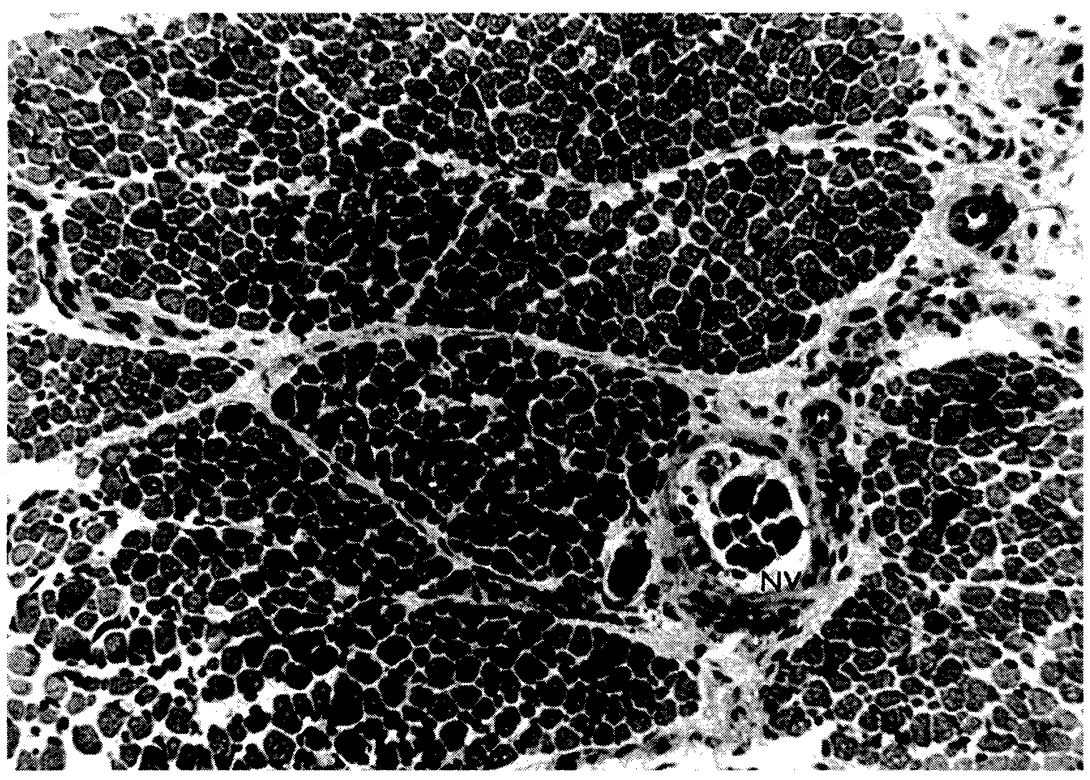

Fig.1.: Neonatal piglet, transversal histological cross-section (CS), m. semimembranosus, markedly compact muscle tissue. Completed morphological differentiation of extra- and intrafusal muscle fibres (MFs), characterised by MFs completely filled with myofibrils, with subsarcolemmally located cell nuclei, polygonal CS, obliteration of differences in thickness between the first and second developmental population of MFs. NMS = neuromuscular spindle; currently occurring intrafibral nuclei, disproportion in the thickness of intrafusal MFs. HE, x 100.

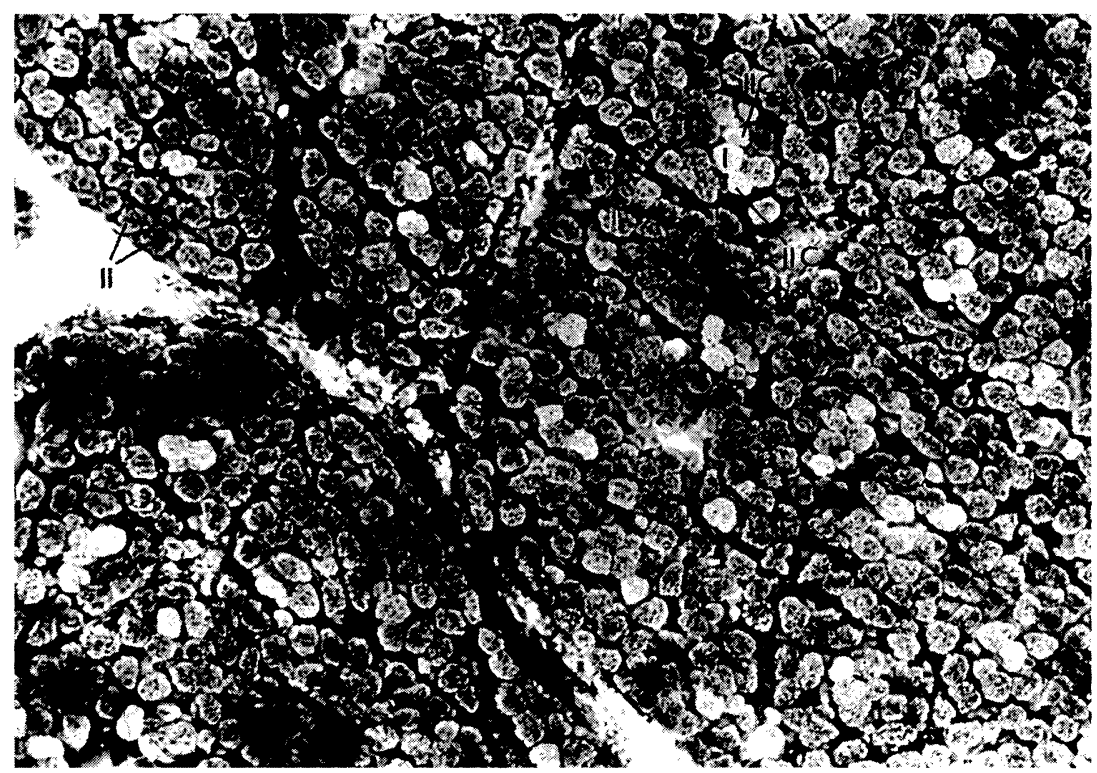

Fig.2.: Neonatal piglets, m.. triceps brachii, c. longum. PAS reaction. Glycogen not only interfibrilarly but also interfascicularly. Intrafibral reaction graded in places, strong in MFs II, weaker in MFs IIC, negative in MFs I (see explanatory notes). x 100. 


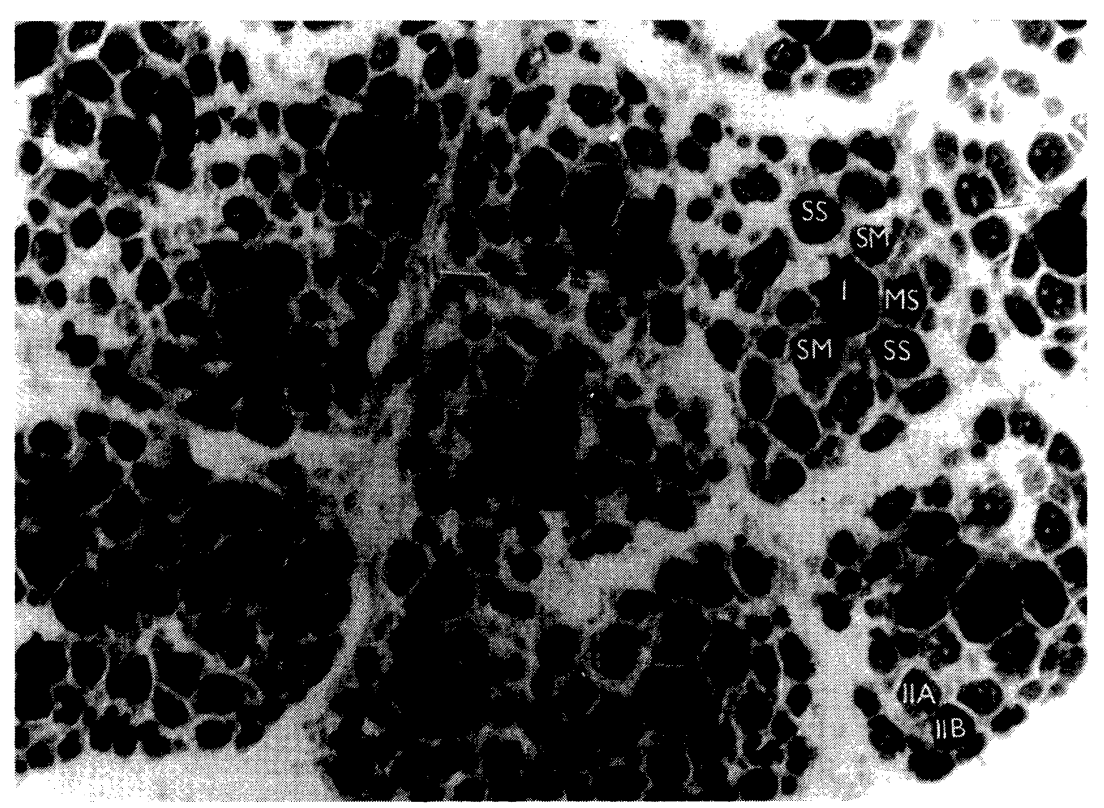

Fig.3a.: Neonatal piglet. CS of a rather superficial, less compact, zone of the m. longissimus dorsi. Primary and secondary muscle bundles (MBs) patterned rather loosely, clearly delineated; muscle fibres of mainly circular CS. Myosin ATPase activity after $\mathrm{pH} 4.3$ preincubation differentiated all basic MF types, including the MS, SS and SM subtypes of the conversion IIC type. Difference in thickness between primary (type I) and secondary type II) muscle fibres still noticeable. MFs adequately filled with myofibrils; $x 160$.

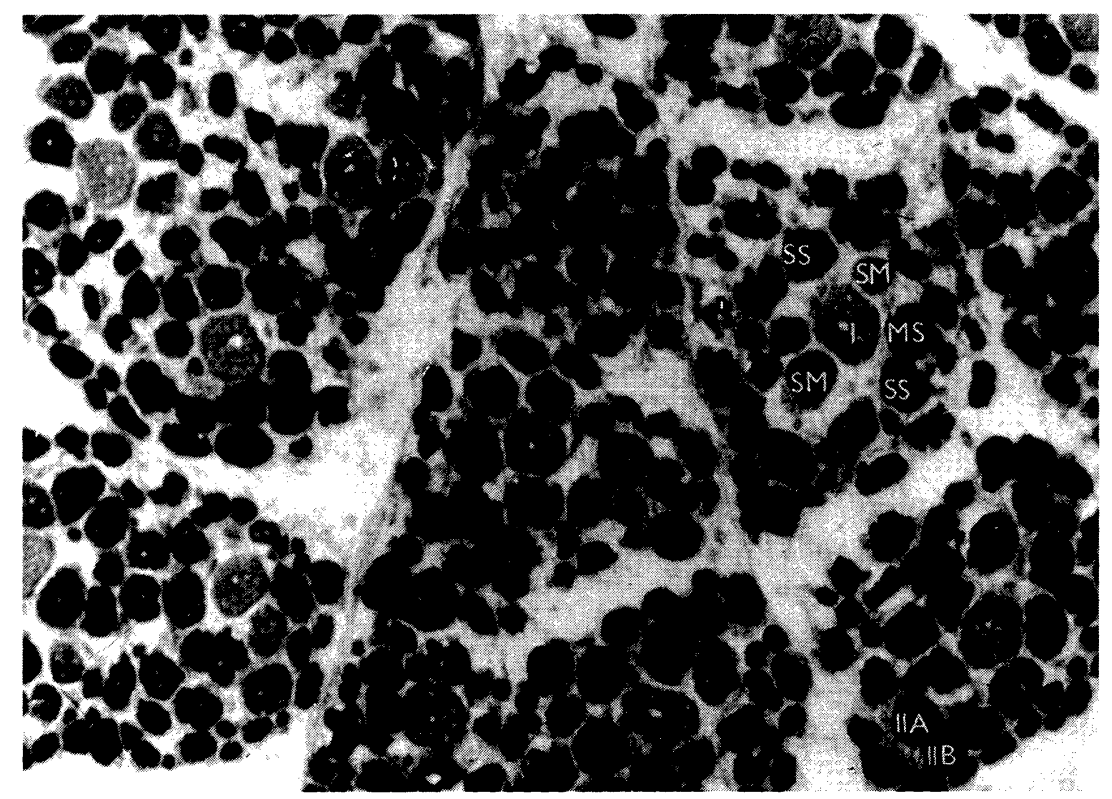

Fig.3b.: Inversion image to 3a: myosin ATPase reaction after alkaline preincubation at $\mathrm{pH} 9.2$. Legend to MF types in both images is identical. $x 160$. 


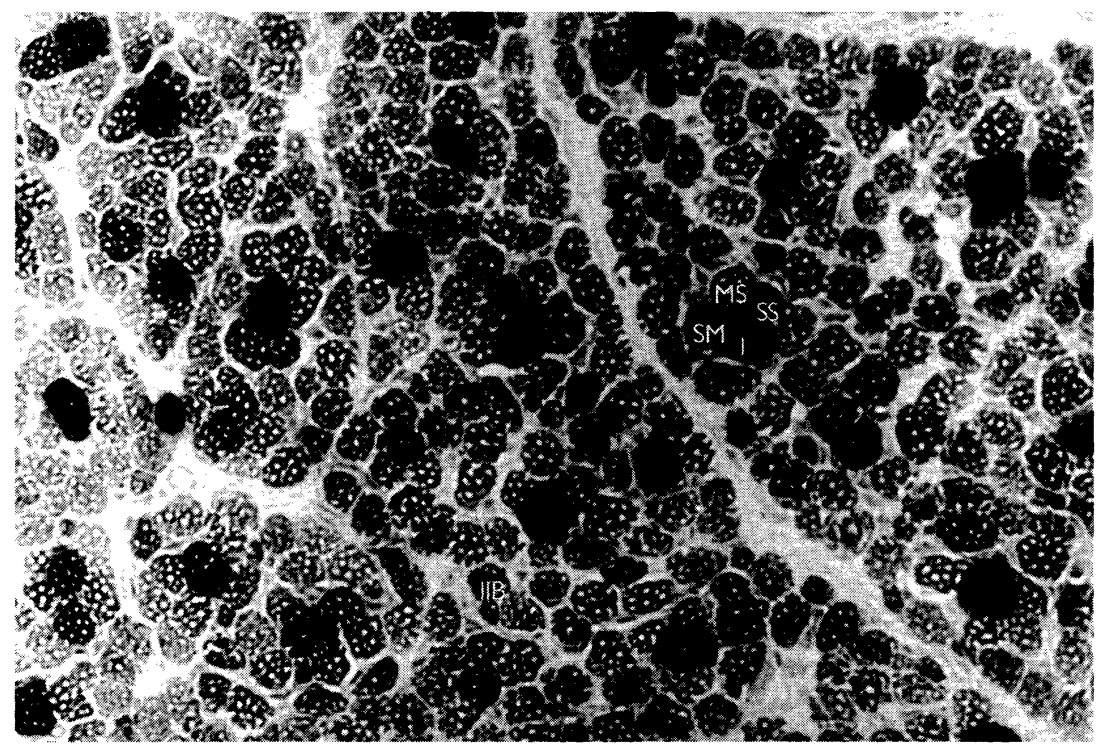

Fig.4.: Neonatal piglet. Myosin ATPase detection after preincubation at $\mathrm{pH} 4.3$ demonstrated a high degree of histochemical and morphological differentiation. The most intensive reaction was observed in the completely acid stable MF I, intensive reaction in conversion MFs with their SS, SM subtypes, and moderate in MS subtype. The reaction also differentiated type II fibres into IIA and IIB. M. gracilis, typical glycolytic muscle with $1 \mathrm{MF}$ of type $\mathrm{I}$ in the primary MB and with absolute predominance of type II fibres; . x 160.

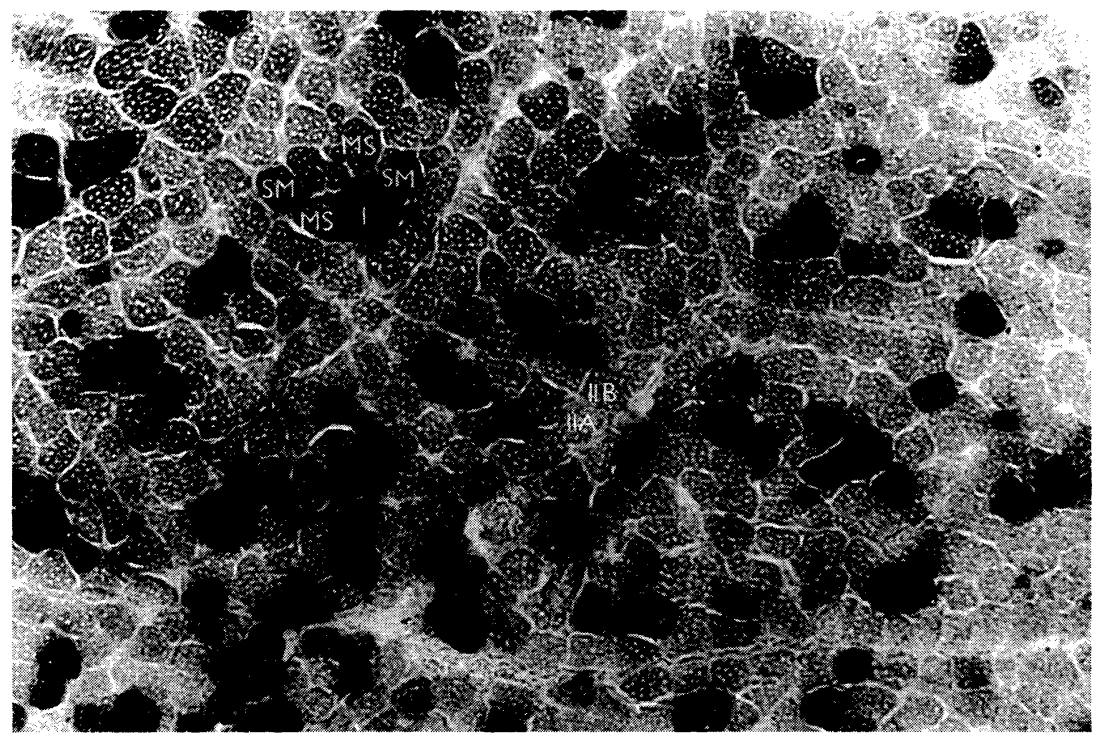

Fig.5.: Neonatal piglet. Series CS from $\mathrm{m}$. tibialis cranialis, as in $\mathrm{m}$. gracilis, ATPase reaction at $\mathrm{pH}$ 4.3 demonstrated 1 (exceptionally 2 ) acid stable type I fibres. Compared to $\mathrm{m}$. gracilis, however, its primary MBs contain a large number (up to 12) conversion MFs, with a predominance of SM subtype, which reacts almost analogically as type I fibres. Polygonal muscle fibres are equally thick and fully filled with myofibrils; $x 100$. 
Plate IV.

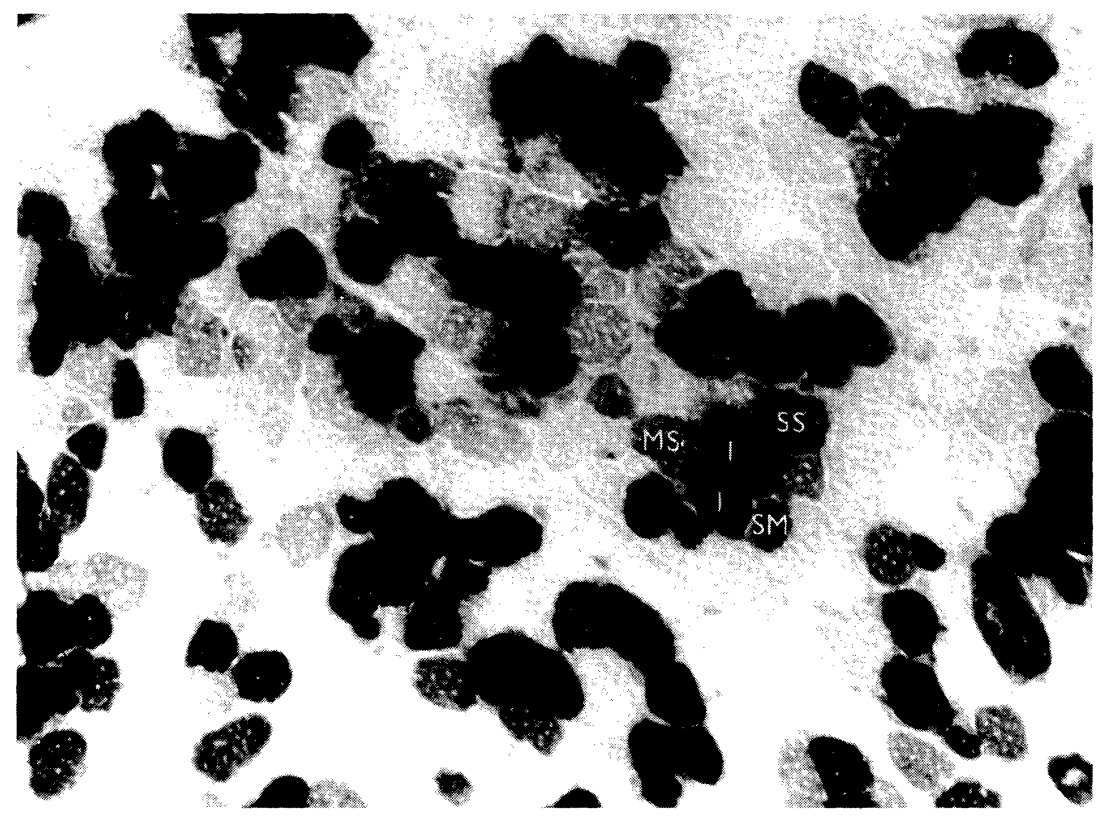

Fig. 6a.: Neonatal piglet. CS from m. sternomastoideus. ATPase at pH 4.3. Mostly one and exceptionally 3 thick, primary acid stable type I fibres in primary MB, very intensive reaction. Conspicuously large number of conversion subtypes (the most advanced SM subtype already converging to type I fibres). In the centre, primary MB with an almost completed conversion of type II fibres into transformation subtypes, with a predominance of MS subtype. $\mathrm{x} 160$.

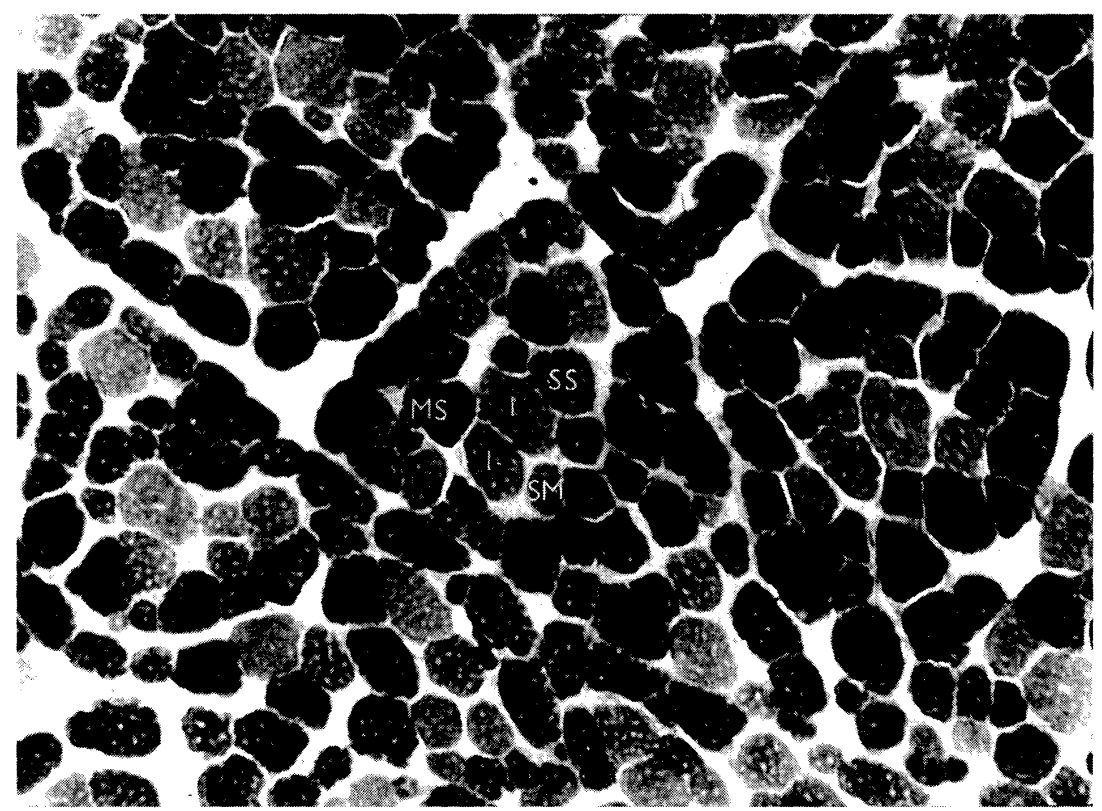

Fig. 6b.: Inversion image of 6a. Myosin ATPase reaction at pH 9.4. x 160. 


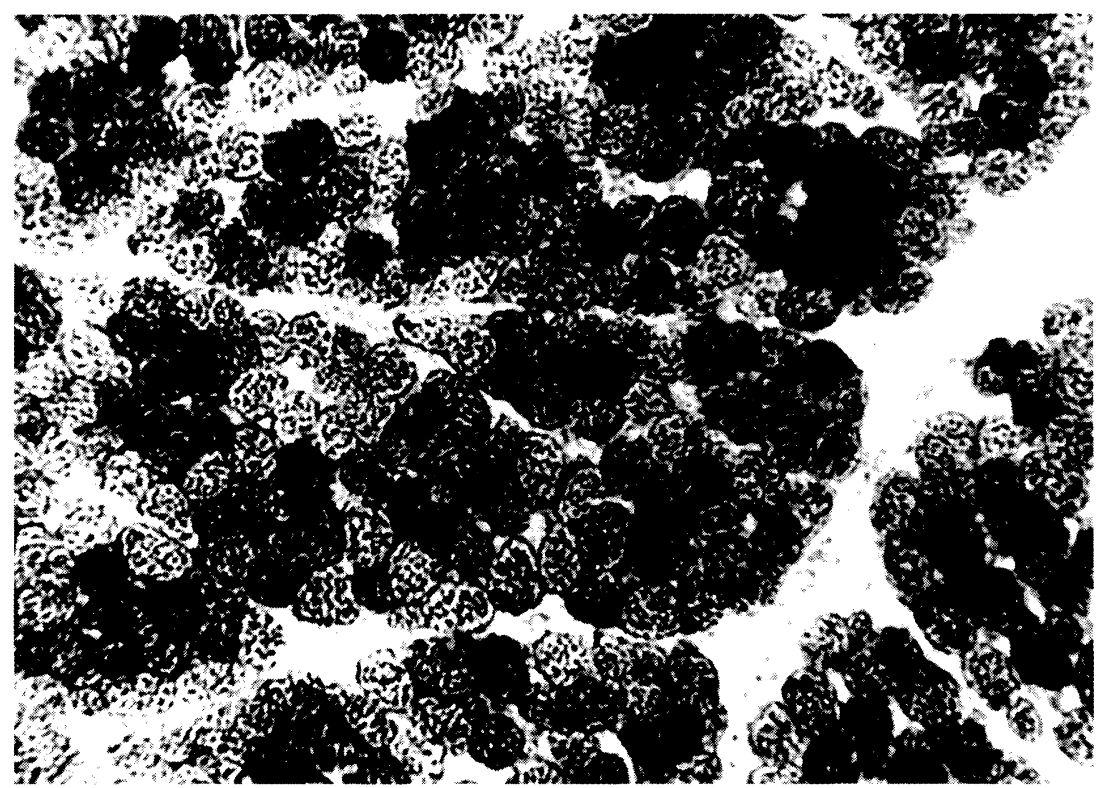

Fig. 7.: Seven-day-old piglet. Muscle fibre type differentiation by SDH reaction in $\mathrm{m}$. longissimus dorsi. Reaction markedly differentiated than in a newborn. Oxidative fibres react with a higher intensity than the rest. Their clear delineation, particularly between individual type II fibres, is still impossible in places; $x 100$.

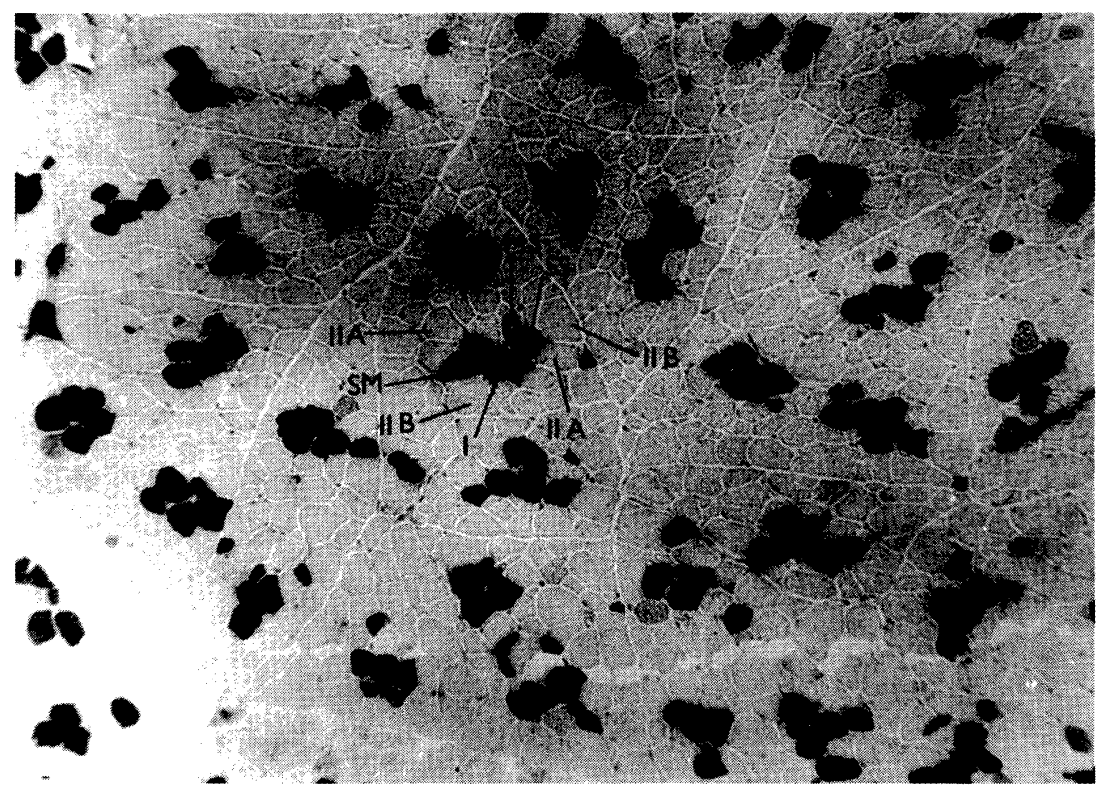

Fig. 8.: One-month-old piglet. $\mathrm{CS}$ from m. triceps brachii. ATPase at $\mathrm{pH}$ 4.5. Although the number of type I fibres has increased from 1 up to 4, type II fibres have retained absolute majority. Numerous transformation subtypes (MS, SS, SM) differentiated by intensity of their reaction, and differentiated type IIA and IIB fibres; $x 63$. 


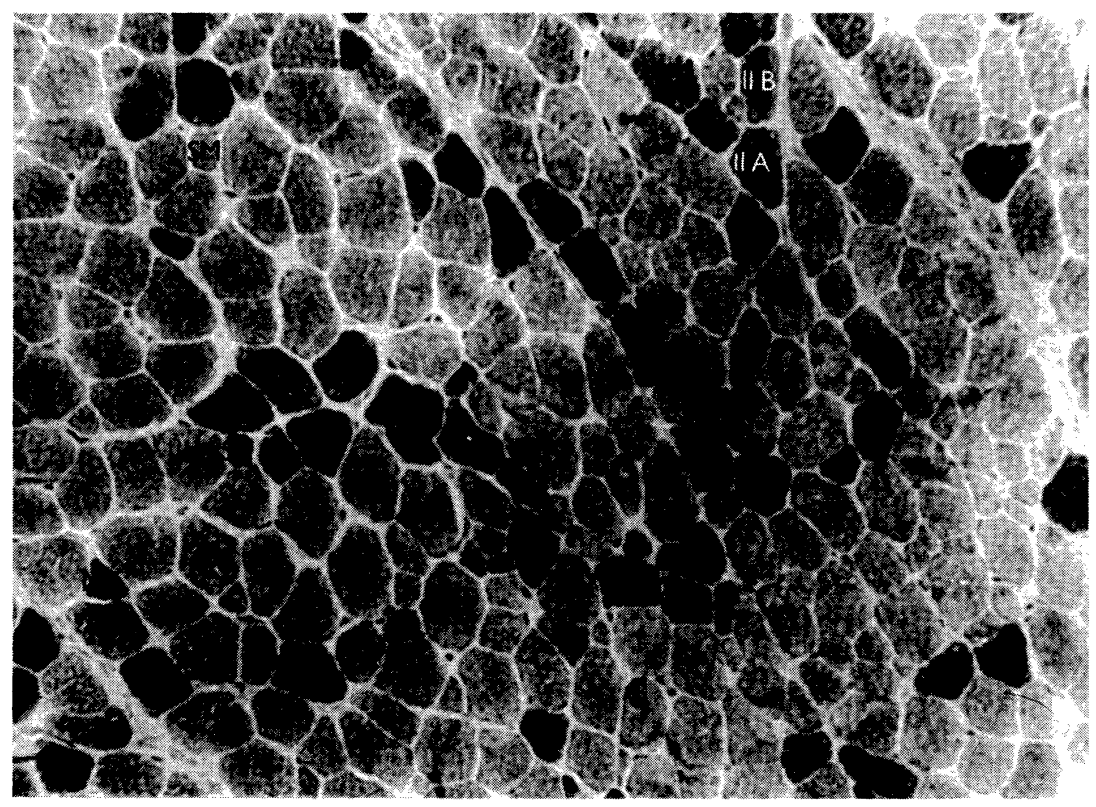

Fig. 9a.: One-month-old piglet Myosin ATPase activity at $\mathrm{pH} 9.4$ in the cross-section from the $\mathrm{m}$. sternomastoideus depicts the opposite situation from that in Fig. 8.: Although primary MBs in neonates contained only 1-3 fibres of type I (light), they now make up an complete majority of fibres in the muscle. Individual transformation MFs and type IIA and IIB fibres can still be found. $x 100$.

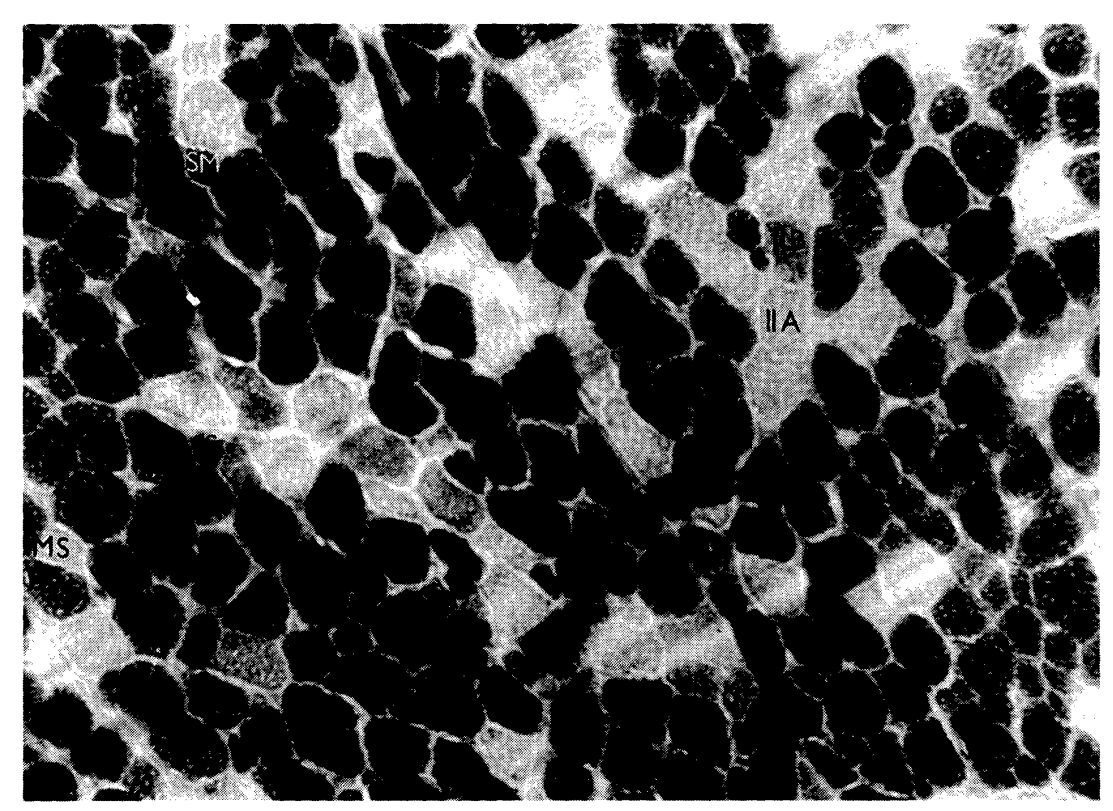

Fig. 9b.: Inversion image of 9a; ATPase at pH 4.35. Acid stable MF I, black. Infrequent MF IIA, IIB and conversion MFs are shown in graded shades grey. $\mathrm{x} 100$. 
Plate VII.

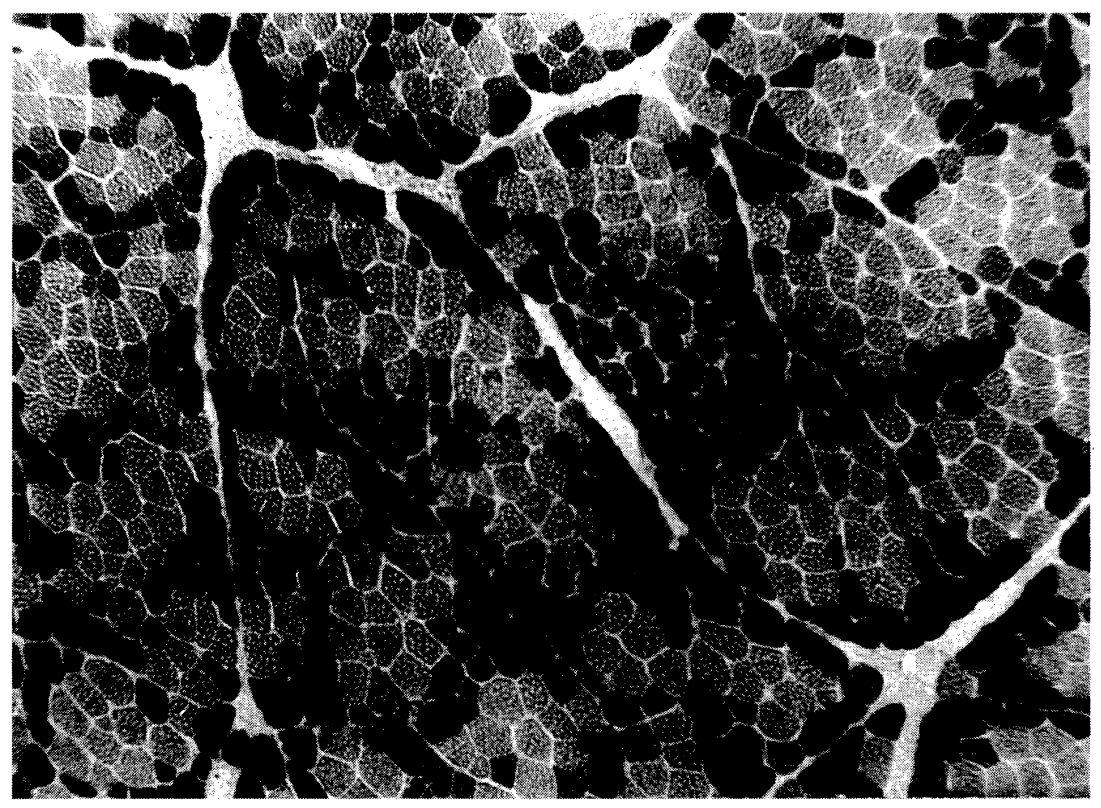

Fig.10.: One-month-old piglet. M. trapezius. ATPase reaction after alkaline preincubation documents the conversion of a muscle with complete predominance of type II fibres into a mixedtype muscle with over $50 \%$ of Type I fibres (the lightest); $x 63$.

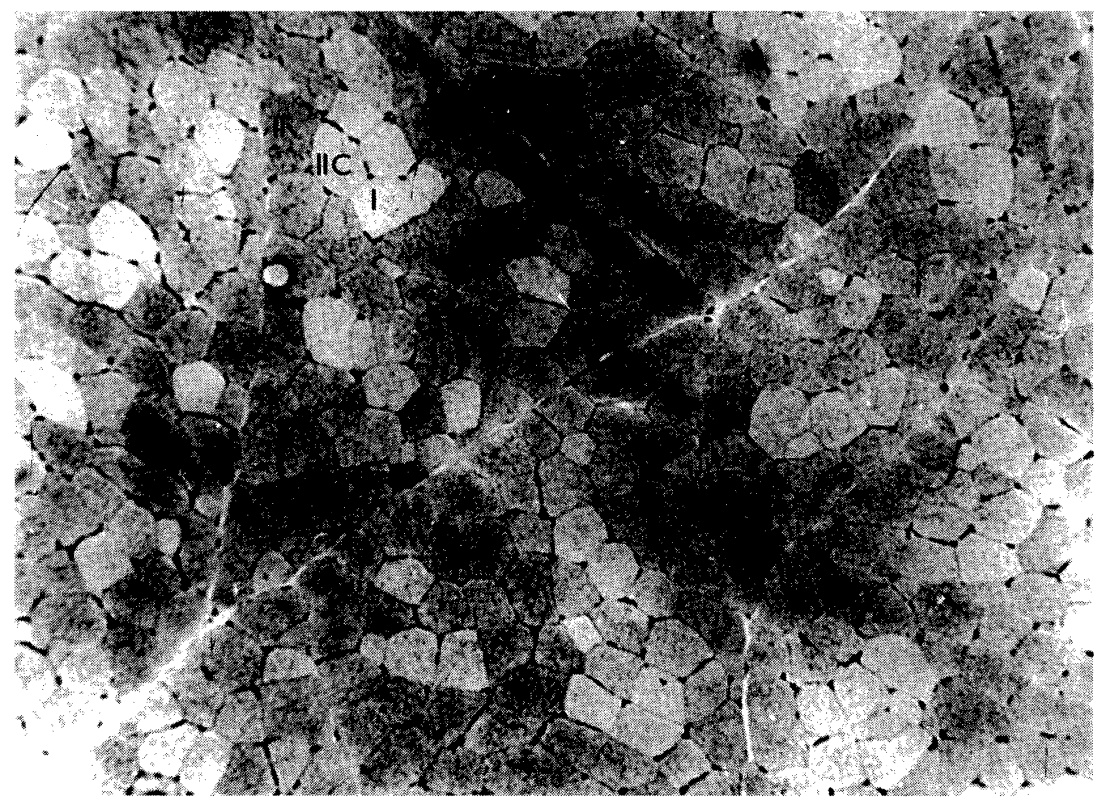

Fig.11.: Three-months-old pig. M. triceps brachii. CS, PAS reaction to glycogen is moderate. Glycogen distribution is not entirely identical with type differentiation of muscle fibres. MF I - the lightest, MF II - the darkest, MF IIC - intermediary; x 63. 


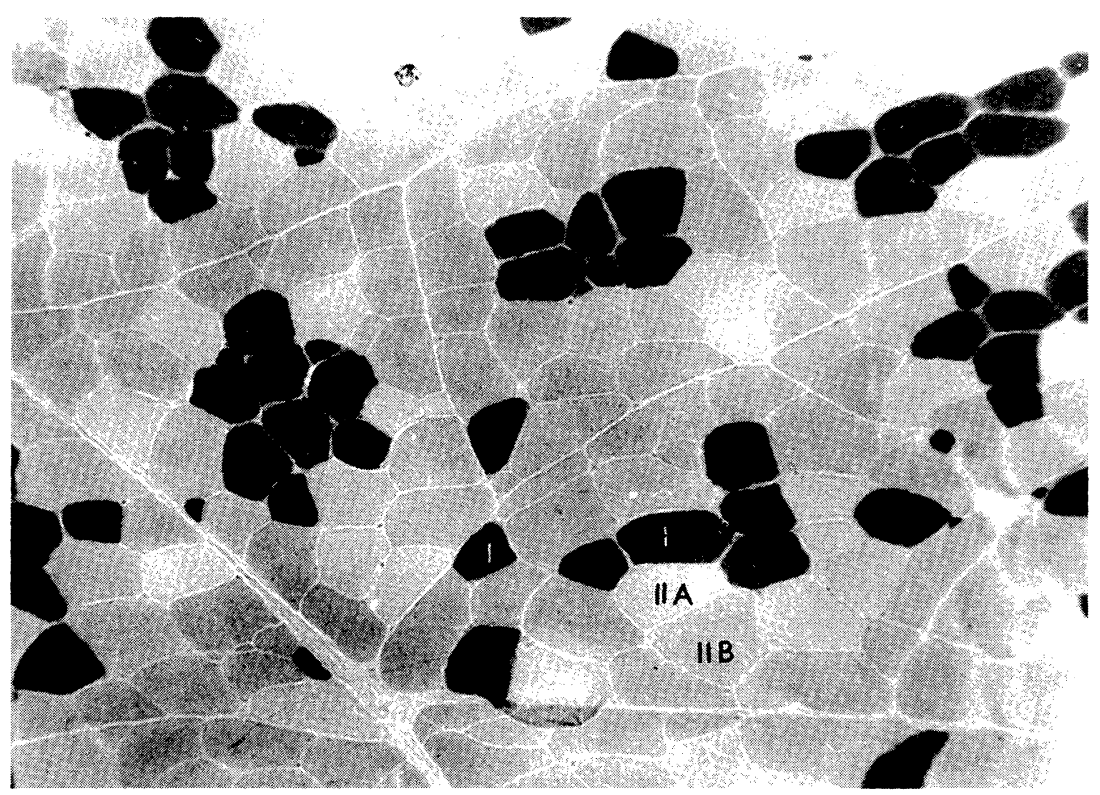

Fig.12a.: Three-month-old pig. Muscle fibre type distribution in $\mathrm{m}$. triceps brachii. The number of MF I (black) is only slightly elevated, dominance of MF II remains highly significant. Lighter MF IIA, darker MF IIB and isolated MF I are clearly identifiable at the periphery of primary bundles. ATPase at $\mathrm{pH} 4.3 . \mathrm{x} 100$.

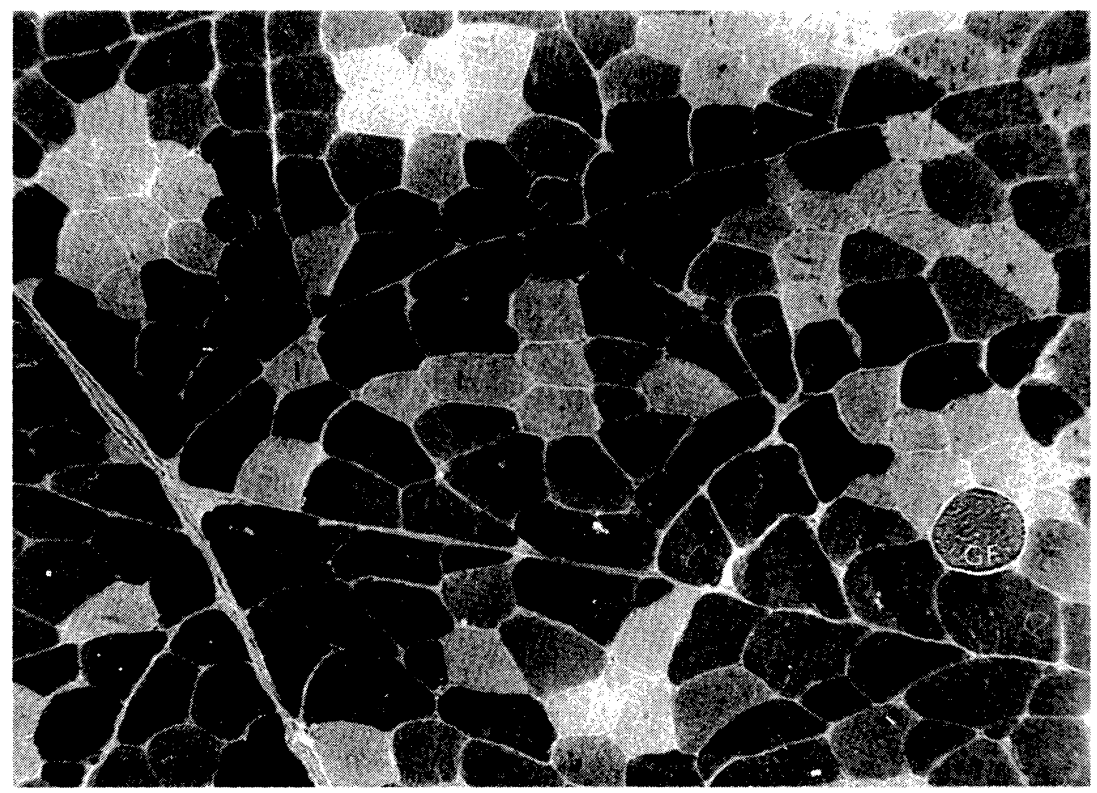

Fig. 12b.: Inversion image of Fig. 12a. ATPase at $\mathrm{pH} 9.4$. In the bottom right part of the picture a ,giant fibre" with dystrophic changes can be seen. x 100 . 


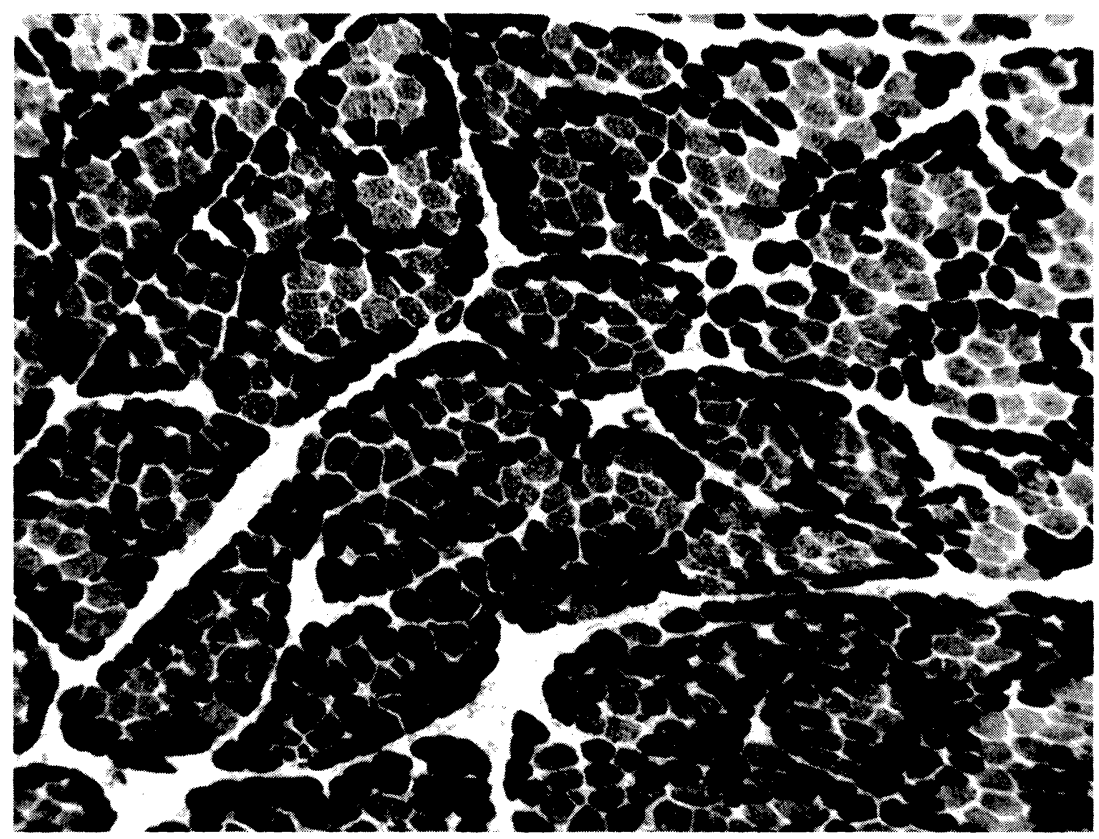

Fig.13a.: Six-month old pig. M. trapezius. ATPase at pH 9.4. Conversion no longer makes any significant progress. Transformation MFs, particularly their more advanced stages, are still clearly identifiable; $x 63$.

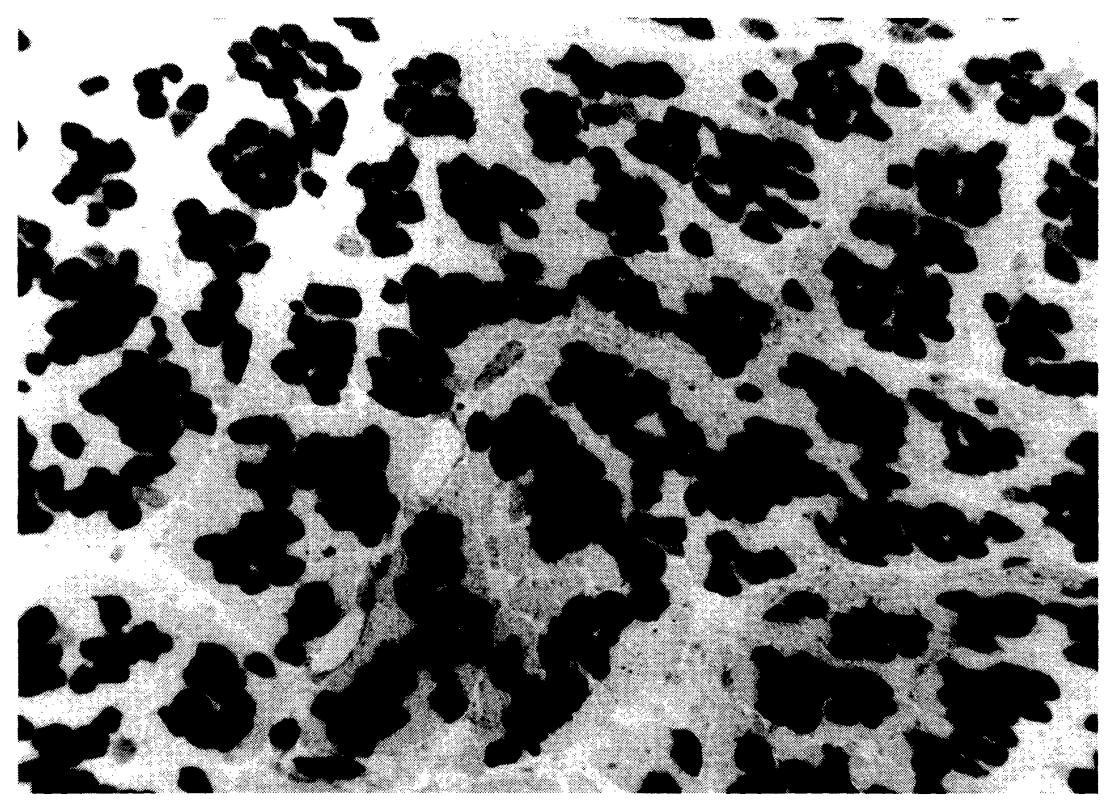

Fig.13b.: Inversion image of Fig.13a. ATPase at pH 4.3; x 63. 


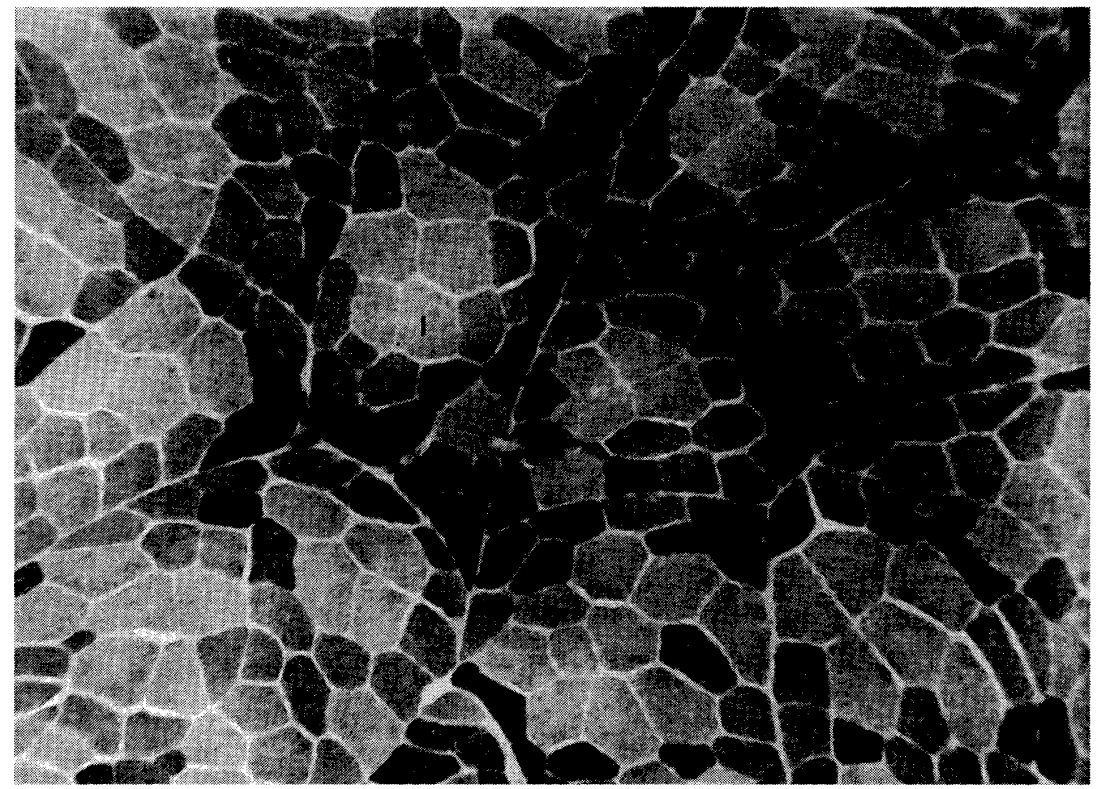

Fig.14.: Six-month-old pig. MF type distribution in $\mathrm{m}$. tibialis cranialis. Routine ATPase. Conversion of type II fibres into type I (the lightest) has not reached $50 \%$. MF II are clearly differentiated into types IIA and IIB; $x 63$.

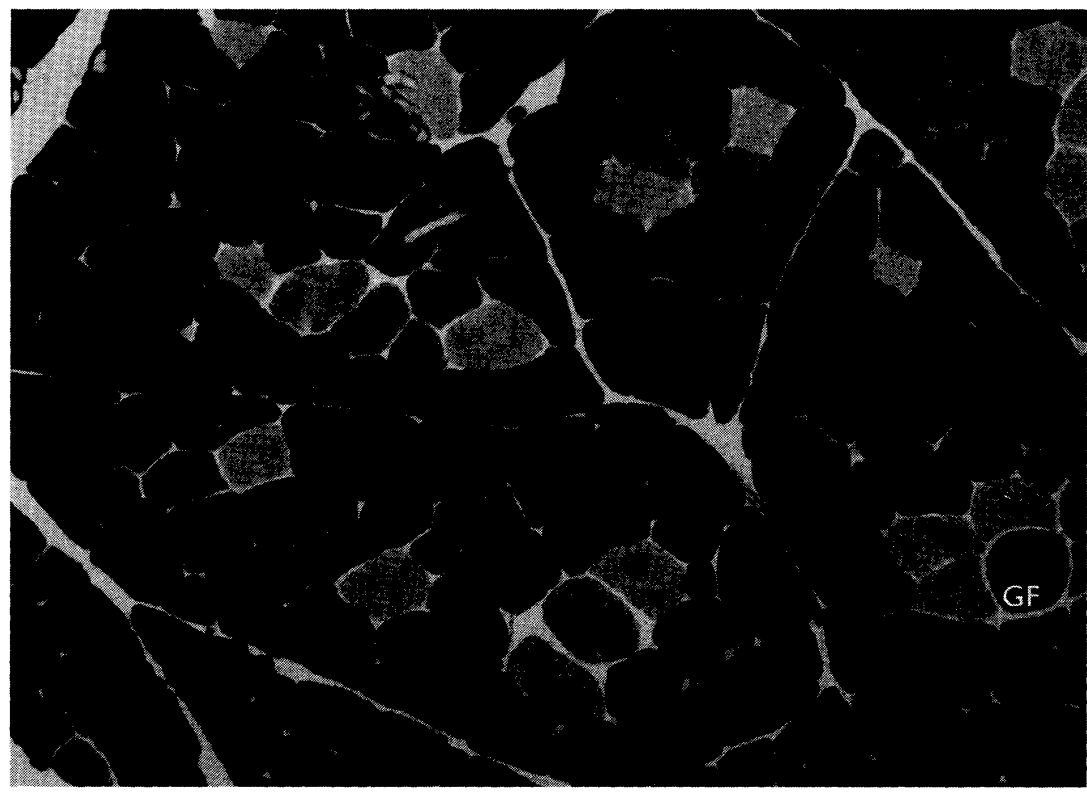

Fig.15.: Six-month-old pig. M. semimembranosus. ATPase at pH 9.4 demonstrates a continued absolute predominance of glycolytic MFs of type II differentiated into MF IIA (grey) and IIB (dark grey). Type I muscle fibres (the lightest) are either in clusters or individually located in primary bundles. A giant fibre can be seen in the bottom right part of the image. 